\title{
The Adjustment of Global External Balances: Does Partial Exchange Rate Pass-Through to Trade Prices Matter?
}

\author{
Christopher Gust \\ Federal Reserve Board \\ Sylvain Leduc \\ Federal Reserve Bank of San Francisco \\ Nathan Sheets \\ Federal Reserve Board
}

June 2008

Working Paper 2008-16

http://www.frbsf.org/publications/economics/papers/2008/wp08-163bk.pdf

The views in this paper are solely the responsibility of the authors and should not be interpreted as reflecting the views of the Federal Reserve Bank of San Francisco or the Board of Governors of the Federal Reserve System. 


\title{
The Adjustment of Global External Balances: Does Partial Exchange Rate Pass-Through to Trade Prices Matter?*
}

\author{
Christopher Gust ${ }^{\dagger}$ \\ Federal Reserve Board \\ Sylvain Leduc \\ Federal Reserve Bank of San Francisco \\ Nathan Sheets \\ Federal Reserve Board
}

June 2008

\begin{abstract}
This paper assesses whether partial exchange rate pass-through to trade prices has important implications for the prospective adjustment of global external imbalances. To address this question, we develop and estimate an open-economy DGE model in which pass-through is incomplete due to the presence of local currency pricing, distribution services, and a variable demand elasticity that leads to fluctuations in optimal markups. We find that the overall magnitude of trade adjustment is similar in a low and high pass-through world with more adjustment in a low passworld occurring through a larger response of the exchange rate and terms of trade rather than real trade flows.
\end{abstract}

Keywords: Exchange rate pass-through, Trade prices, Trade balance

JEL classification: F3, F41

\footnotetext{
${ }^{*}$ The authors thank Chris Erceg, Joseph Gagnon, Luca Guerrieri, Dale Henderson, Karen Johnson, Steven Kamin, Jaime Marquez, and Trevor Reeve for useful comments and suggestions. The views expressed in this paper are solely the responsibility of the authors and should not be interpreted as reflecting the views of the Board of Governors of the Federal Reserve System or of any other person associated with the Federal Reserve System.

${ }^{\dagger}$ Corresponding Author: Christopher Gust, Address: Federal Reserve Board, Mail Stop 42, Washington DC, 20551, Telephone: 202-452-2383, Fax: 202-872-4926. Email addresses: christopher.gust@frb.gov and nathan.sheets@frb.gov.
} 


\section{Introduction}

The U.S. current account deficit widened significantly over the past 15 years, reaching more than 6 percent of GDP in 2006. This situation has raised concerns among policymakers about how the deficit may unwind, with some observers arguing that the turnaround in the current account deficit could be dramatic, triggering a large dollar depreciation and significant sectoral adjustment along the way. ${ }^{1}$ Although the relative flexibility of U.S. labor markets and competitiveness of the U.S. economy in general may help during the adjustment process, policymakers worry that the presence of other frictions could hinder the adjustment of the trade balance.

One such often-mentioned friction is the well-documented lack of responsiveness of U.S. import prices to movements in the exchange rate (i.e., low exchange rate pass-through). In principle, low pass-through could considerably diminish the response of the trade balance to shocks by muting the effects on trade prices. As a result, consumers would have less incentive to alter their spending patterns, hampering the adjustment process. In this vein, Obstfeld and Rogoff (2004) conjecture that, to engineer the necessary changes in relative prices, the dollar depreciation consistent with eliminating the U.S. current account deficit would need to be much larger in a world of low pass-through.

In this paper, we evaluate these arguments by examining the relationship between incomplete exchange rate pass-through to trade prices and the trade balance using a two-country, DGE model. Our framework incorporates three complementary mechanisms that generate incomplete pass-through to trade prices. First, pass through to import prices at the dock is low because, as in Bergin and Feenstra (2001), Bouakez (2005), and Gust, Leduc, and Vigfusson (2006), firms face a non-constant elasticity of demand, which leads to optimal markup variations that reduce the sensitivity of trade prices to changes in the exchange rate. Second, the presence of nominal rigidities combined with local currency pricing also reduces the extent of pass-through at the dock. Finally, following Burstein, Neves, and Rebelo (2003), we introduce

\footnotetext{
${ }^{1}$ See, for example, Obstfeld and Rogoff (2000b), Edwards (2005), or Blanchard, Giavazzi, and Sa (2004). For a more benign view, see Backus, Henriksen, Lambert, and Telmer (2006). For other explanations of the large U.S. current account deficits, see Caballero, Fahri, and Gourinchas (2006), Engel and Rogers (2006), Faruqee, Laxton, Muir, and Pesenti (2005), and Mendoza, Quadrini, and Rios-Rull (2007).
} 
a distribution sector intensive in local non-tradables to lower pass through to import prices at the retail level. By estimating our model, we show that each of these mechanisms is important in accounting for key features of U.S. data.

Our main finding is that the extent of pass-through does not significantly alter the response of the nominal trade balance to shocks. In a low pass-through world, the sensitivity of the real economy to changes in the exchange rate is muted, which inhibits external adjustment. In addition, the response of the exchange rate to shocks is amplified in a low pass-through environment, which helps engender more nominal adjustment. For our benchmark estimates, we find that these two effects largely offset so that the nominal trade balance responds by roughly the same magnitude in a low and high pass-through environment. However, the forces underlying movements in the trade balance are very different with more adjustment in a low pass-world occurring through a larger response of the exchange rate and terms of trade rather than real trade flows.

We show that this result is not very sensitive to the relative importance of the three features that account for low pass-through, but it does depend critically on the value of the elasticity of substitution between home and foreign goods. Our benchmark estimate of this elasticity is just below one, and we find that a low pass-through environment only inhibits nominal trade adjustment when this elasticity is much higher in both the short and long-run. While such high elasticities - in the range of 6 to 15 - are typically found in studies examining the response of trade volumes to permanent tariff changes over long horizons, such high elasticities are more difficult to justify over shorter horizons, as trade volumes appear relatively unresponsive to trade prices at business cycle frequencies. We modify our benchmark model to incorporate costs of adjusting imports as in Erceg, Guerrieri, and Gust (2006) or Engel and Wang (2007) so that the model is consistent with both sets of evidence. In this case, as in the benchmark model, the response of the nominal trade balance to shocks is roughly the same in the low and high pass-through worlds.

All told, we view our results as providing some comfort that trade adjustment can still occur even in economies facing relatively unresponsive trade prices, albeit via larger exchange 
rate depreciation and terms of trade movements than higher trade volumes. Indeed, recent evidence indicates that pass-through to U.S. import prices is well below unity and has been declining. For instance, Marazzi and Sheets (2007) report that pass-through to "core" import prices (i.e., excluding computers, semiconductors, and oil) fell from 50 percent in the 1970s and 1980s to roughly 20 percent during the past decade. Recent analyses by the BIS (2005) and the IMF (2005) have found broadly similar results. Campa and Goldberg (2005) do not find a decline in pass-through to import prices, but nevertheless conclude that it remains quite low at approximately 40 percent.

The remainder of our paper is organized as follows. The next section presents our openeconomy model. We then describe our approach for estimating key model parameters and present our main results. In doing so, we conduct extensive sensitivity analysis, showing that our results are robust to different monetary policy rules and to variations in the relative importance of the three features that account for incomplete pass-through. Finally, we offer a brief conclusion.

\section{The Model}

Our model consists of a home and a foreign economy. These two economies have isomorphic structures so in our exposition we focus on describing only the domestic economy. The domestic economy consists of households, producers of an aggregate tradable and non-tradable good, and a government sector. Each country in effect produces both an aggregate tradable and non-tradable good, although we adopt a monopolistically-competitive framework to rationalize price stickiness of both non-tradable and tradable prices.

We introduce three mechanisms into the model to reduce the sensitivity of import prices to changes in the exchange rate. First, we allow for a distribution sector as in Burstein, Neves, and Rebelo (2003) that requires a significant non-tradable component and lowers the sensitivity of retail import prices to exchange rate movements. Second, as in Betts and Devereux (1999), we assume that trade prices are sticky in local currency terms. Finally, as in Gust, Leduc, 
and Vigfusson (2006), we use Kimball (1995)-type demand curves so that a firm's export price depends on the prices of its competitors, giving rise to optimal markup variation that induces incomplete pass-through.

\subsection{Households}

The utility function of the representative household in the home country is

$$
E_{t} \sum_{j=0}^{\infty} \beta^{j}\left(\frac{C_{t}^{1-\sigma}}{1-\sigma}-\frac{\chi_{0} L_{t+j}^{1+\chi}}{1+\chi}\right),
$$

where $C_{t}$ denotes consumption, and $L_{t}$ denotes labor hours. The discount factor $\beta$ satisfies $0<$ $\beta<1$, and $E_{t}$ is the expectation operator conditional on information available at time $t$. A household faces a flow budget constraint in period $t$ which states that its expenditures and net accumulation of financial assets must equal its disposable income:

$$
P_{t} C_{t}+P_{t} I_{t}+\int_{s} \xi_{t, t+1} B_{D t+1}-B_{D t}+\frac{e_{t} P_{B t}^{*} B_{F t+1}}{\phi_{b t}}-e_{t} B_{F t}=W_{t} L_{t}+R_{K t} K_{t}+\Omega_{t}-T_{t}
$$

A household's disposable income consists of its labor income $\left(W_{t} L_{t}\right)$, income from renting capital to firms $\left(R_{K t} K_{t}\right)$, and an aliquot share of the profits of the firms located in the home country $\left(\Omega_{t}\right)$. Households also pay lump-sum taxes $\left(T_{t}\right)$ and purchase consumption and investment $\left(I_{t}\right)$ at price, $P_{t}$. A household's investment augments capital according to:

$$
K_{t+1}=(1-\delta) K_{t}+I_{t}
$$

We assume that a household can engage in frictionless trading of a complete set of contingent claims with other domestic households. We denote $\xi_{t, t+1}$ as the price of an asset that pays one unit of domestic currency in a particular state of nature at date $t+1$, while $B_{D t+1}$ represents the quantity of such claims purchased by a household at time $t$.

While asset markets are complete within a country, we assume that trade in international assets is restricted to a non-state contingent nominal bond. Accordingly, in equation (2), $B_{F t+1}$ represents the quantity of a non-state contingent asset purchased at time $t$ that pays one unit of foreign currency in the subsequent period, and $P_{B t}^{*}$ is the foreign currency price of the bond. 
We follow Turnovsky (1985) and assume there is an intermediation cost $\phi_{b t}$ paid by households in the home country for purchases of foreign bonds, which is necessary to ensure that net foreign assets are stationary in equilibrium. ${ }^{2}$ More specifically, the intermediation costs depend on the ratio of economy-wide holdings of net foreign assets to nominal output and are given by:

$$
\phi_{b t}=\exp \left[-\phi_{b}\left(\frac{e_{t} B_{F t+1}^{A}}{P_{Y t} Y_{t}}\right)\right] .
$$

In every period $t$, a household maximizes the utility functional (1) with respect to consumption, investment, the end-of-period capital stock, labor, holdings of domestic contingent claims, and holdings of the international asset subject to its budget constraint (2) and the evolution of capital (3). In doing so, a household takes as given prices and aggregate quantities such as the aggregate net foreign asset position.

\subsection{Final Good Production}

The economy's final good $\left(A_{t}\right)$ is used for consumption, investment, and government consumption. This final good is produced by perfectly competitive firms who purchase a non-traded good, $A_{N t}$, and traded good, $A_{T t}$, at prices $P_{N t}$ and $P_{T t}^{R}$. (We use an "R" superscript to denote the retail price of the traded good to distinguish it from its wholesale price $P_{T t}$.) The final good is produced via a CES aggregator:

$$
A_{t}=\left[\phi^{\frac{\rho_{a}}{1+\rho_{a}}} A_{N t}^{\frac{1}{1+\rho_{a}}}+(1-\phi)^{\frac{\rho_{a}}{1+\rho_{a}}} A_{T t}^{\frac{1}{1+\rho_{a}}}\right]^{1+\rho_{a}},
$$

where $\phi$ and $1-\phi$ are the weights on the non-traded and traded goods and $\frac{1+\rho_{a}}{\rho_{a}}$ denotes the constant elasticity between these goods.

A representative final goods producer sells its good to households and the government at price $P_{t}$ and chooses its purchases of non-traded and traded goods to maximize its profits:

$$
\max P_{t} A_{t}-P_{N t} A_{N t}-P_{T t}^{R} A_{T t}
$$

subject to equation (5).

\footnotetext{
2 This intermediation cost is asymmetric, as foreign households do not face these costs. Rather, they collect profits on the monopoly rents associated with these intermediation costs. As discussed in Schmitt-Grohe and Uribe (2003), this way of closing the model delivers similar dynamics to other alternative approaches.
} 


\subsection{Non-traded Good Production}

The economy's non-traded good is produced by perfectly competitive firms who combine a continuum of differentiated products, $A_{N t}(i), i \in[0,1]$, according to the demand aggregator, $\int_{0}^{1} D_{N}\left(A_{N t}(i)\right) d i=1$. We follow Dotsey and King (2005) and assume that the functional form of the demand aggregator is given by:

$$
\int_{0}^{1} D_{N}\left(A_{N t}(i)\right) d i=\int_{0}^{1} \frac{1}{(1-\nu) \gamma}\left[(1-\nu) \frac{A_{N t}(i)}{A_{N t}}+\nu\right]^{\gamma} d i-\frac{1}{(1-\nu) \gamma}+1 .
$$

A representative non-traded goods producer chooses $A_{N t}$ and its purchases of differentiated products to maximize profits:

$$
\max P_{N t} A_{N t}-\int_{0}^{1} P_{N t}(i) A_{N t}(i) d i
$$

subject to equation (7) taking $P_{N t}$ and the prices of the differentiated goods, $P_{N t}(i)$, as given. Profit maximization implies that the demand for non-traded good $i$ is given by:

$$
A_{N t}(i)=\left[\frac{1}{1-\nu}\left(\frac{P_{N t}(i)}{\bar{P}_{N t}}\right)^{\frac{1}{\gamma-1}}-\frac{\nu}{1+\nu}\right] A_{N t}
$$

In equation (9), $\bar{P}_{N t}$ is a Dixit-Stiglitz price index:

$$
\bar{P}_{N t}=\left(\int_{0}^{1} P_{N t}(i)^{\frac{\gamma}{\gamma-1}} d i\right)^{\frac{\gamma-1}{\gamma}}
$$

while the price of non-traded goods can be related to the prices of the differentiated goods via:

$$
P_{N t}=\frac{1}{1-\nu} \bar{P}_{N t}-\frac{\nu}{1-\nu} \int_{0}^{1} P_{N t}(i) d i
$$

From equation (9), it is clear that with $\nu \neq 0$, the demand curve has a Dixit-Stiglitz component as well as an additive linear term. The presence of this additive linear term gives rise to a variable elasticity of substitution (VES) in which the elasticity depends on $P_{N t}(i)$ relative to the price of a firm's competitors, $\bar{P}_{N t}$. In particular, as in Kimball (1995), when $\nu>0$, the demand elasticity can be expressed as an increasing function of a firm's relative price. This variable demand elasticity gives rise to complementarities in price setting and has proven useful in the sticky price literature, because it reduces a firm's incentive to change its price, improving 
the ability of these models to account for inflation dynamics. ${ }^{3}$. Another attractive property of this demand aggregator is that it nests Dixit-Stiglitz aggregator in which the elasticity of demand is constant when $\nu=0$.

\subsection{Traded Goods Production}

The economy's traded good is produced by perfectly competitive firms who combine a continuum of domestically-produced differentiated products, $A_{H t}(i), i \in[0,1]$, and imported goods, $A_{F t}(i), i \in[0,1]$, according to the demand aggregator:

$$
\int_{0}^{1} D_{T}\left(A_{H t}(i), A_{F t}(i)\right) d i=\left[V_{H t}^{1 / \rho}+V_{F t}^{1 / \rho}\right]^{\rho}-\frac{1}{(1-\nu) \gamma}+1,
$$

where $V_{H t}$ is an aggregator of domestically-produced goods given by:

$$
V_{H t}=\int_{0}^{1} \frac{(1-\omega)^{\rho}}{(1-\nu) \gamma}\left[\frac{(1-\nu)}{1-\omega} \frac{A_{H t}(i)}{A_{T t}}+\nu\right]^{\gamma} d i,
$$

and $V_{F t}$ is an aggregator of imported goods given by:

$$
V_{F t}=\int_{0}^{1} \frac{\omega^{\rho}}{(1-\nu) \gamma}\left[\frac{(1-\nu)}{\omega} \frac{A_{F t}(i)}{A_{T t}}+\nu\right]^{\gamma} d i .
$$

Our demand aggregator is similar to the one in Gust, Leduc, and Vigfusson (2006), who extend the Dotsey and King (2005) aggregator to an international environment. ${ }^{4}$ Similar to the aggregator for non-traded goods, this aggregator also has a variable elasticity for $\nu \neq 0$ and a constant elasticity for $\nu=0$. The parameter $\omega$ can be thought of as indexing the share of imports in traded goods production.

This aggregator allows the elasticity of substitution between a home and foreign good to differ from the demand elasticity for two home goods. When $\nu=0$, this demand aggregator simplifies to one used by Chari, Kehoe, and McGrattan (2002), whose aggregator can be thought as the combination of a Dixit-Stiglitz and Armington aggregator. In equations (12)-(14), $\gamma$ influences the elasticity of substitution between two home brands. The elasticity of substitution

\footnotetext{
3 See, for example, Dotsey and King (2005), Eichenbaum and Fischer (2007) and Guerrieri, Gust, and López-Salido (2008).

${ }^{4}$ See Gust, Leduc, and Vigfusson (2006) for a discussion of the properties of this demand aggregator.
} 
between a home and a foreign good is influenced by both $\gamma$ and $\rho$. This property gives the model the flexibility to match empirical estimates of average, economy-wide markups and the responsiveness of aggregate trade flows to relative price changes.

A representative traded goods producer chooses its purchases of differentiated imports and domestically-produced goods as well as $A_{T t}$ to maximize its profits:

$$
\max P_{T t} A_{T t}-\int_{0}^{1} P_{H t}(i) A_{H t}(i) d i-\int_{0}^{1} P_{F t}(i) A_{F t}(i) d i
$$

subject to equations (12)-(14). In the above, $P_{T t}$ denotes the wholesale price of the traded good, which differs from the retail price $P_{T t}^{R}$ due to the presence of a perfectly competitive distribution sector. More specifically, we follow Erceg and Levin (1996), Burstein, Neves, and Rebelo (2003), and Corsetti, Dedola, and Leduc (2008a) by assuming that bringing one unit of the traded good to the final goods producers requires $\eta$ units of the non-traded good. Consequently, the retail price of the traded good reflects a non-traded component, since:

$$
P_{T t}^{R}=P_{T t}+\eta P_{N t}
$$

An important implication of this distribution sector is that exchange rate pass-through of retail import prices will be lower than for wholesale import prices, since distribution services make up an important component of the retail price.

Profit maximization by a representative traded goods producer implies that its demand for import good $i$ is given by:

$$
A_{F t}(i)=\omega\left[\frac{1}{1-\nu}\left(\frac{P_{F t}(i)}{P_{F t}}\right)^{\frac{1}{\gamma-1}}\left(\frac{P_{F t}}{\bar{P}_{T t}}\right)^{\frac{\rho}{\gamma-\rho}}-\frac{\nu}{1-\nu}\right] A_{T t} .
$$

In equation (17), $P_{F t}$ is the wholesale price index for imported goods given by:

$$
P_{F t}=\left(\int_{0}^{1} P_{F t}(i)^{\frac{\gamma}{\gamma-1}} d i\right)^{\frac{\gamma-1}{\gamma}}
$$

and $\bar{P}_{T t}$ is price index consisting of the prices of a firm's competitors satisfying:

$$
\bar{P}_{T t}=\left[(1-\omega) P_{H t}^{\frac{\gamma}{\gamma-\rho}}+\omega P_{F t}^{\frac{\gamma}{\gamma-\rho}}\right]^{\frac{\gamma-\rho}{\gamma}},
$$


where $P_{H t}$ is a wholesale price index for domestic goods defined similarly to equation (18).

Similar to the demand curve for non-traded good, the demand for an imported good, equation (17) has an additive term that leads to an elasticity of demand for imported good $i$ that depends on $P_{F t}(i)$ relative to the prices of its competitors. When the absolute value of the demand elasticity is increasing in a firm's relative price, exchange rate pass-through to wholesale import prices will be incomplete.

Profit maximization implies a similar expression for the demand of $A_{H t}(i)$ expressed as a function of $P_{H t}(i), \bar{P}_{T t}$, and $P_{H t}$, the wholesale price index for domestically-produced goods. It also implies that the wholesale price of the traded good paid to the traded goods producer is:

$$
P_{T t}=\frac{1}{1-\nu} \bar{P}_{T t}-\frac{\nu}{1-\nu}\left[(1-\omega) \int_{0}^{1} P_{H t}(i) d i+\omega \int_{0}^{1} P_{F t}(i) d i\right] .
$$

\subsection{Intermediate Traded Goods Producers}

The producer of traded good $i$ is a monopolistically competitive firm, which sells its good to producers of the aggregate traded good located at home and abroad. A producer utilizes capital and labor to produce its good according to:

$$
Y_{t}(i)=Z_{T t} K_{t}(i)^{\alpha} L_{t}(i)^{1-\alpha}
$$

where $Z_{T t}$ is a shock to the level of technology in the traded goods sector. Since capital and labor are completely mobile within a country, all intermediate traded goods producers have have identical marginal cost per unit of output, $M C_{T t}$.

We consider two alternatives for a traded good firm's price setting decisions. In the first case, we assume that markets are segmented and a firm sets different prices at home and abroad according to Calvo-style contracts. We follow Betts and Devereux (1999) among others and specify the contract price in local currency terms, and call this first alternative local currency pricing (LCP). In the second case, we assume that firms practice producer currency pricing. 


\subsubsection{Local Currency Pricing/Pricing to Market}

For its domestic price setting decision, firm $i$ faces the constant probability $1-\theta_{H}$ of being able to re-optimize its price, and we assume this probability is independent across time, firms, and countries. In choosing its price for the domestic market, $P_{H t}(i)$, a traded goods firm maximizes:

$$
E_{t} \sum_{j=0}^{\infty} \psi_{t+j} \theta_{H}^{j}\left[P_{H t}(i)-M C_{T t+j}\right] A_{H t+j}(i),
$$

taking $\psi_{t+j}, M C_{T t+j}$, and its demand schedule as given. In the above, $\psi_{t+j}$ is the stochastic discount factor with steady state value, $\beta .^{5}$ The first-order condition from this problem is:

$$
E_{t} \sum_{j=0}^{\infty} \psi_{t+j} \theta_{H}^{j}\left[1-\left(1-\frac{M C_{T t+j}}{P_{H t}(i)}\right) \epsilon_{H t+j}(i)\right] A_{H t+j}(i)=0
$$

where the elasticity of demand for traded good $i$ in the domestic market is:

$$
\epsilon_{H t}(i)=\frac{1}{1-\gamma}\left[1-\nu\left(\frac{P_{H t}(i)}{P_{H t}}\right)^{\frac{1}{1-\gamma}}\left(\frac{P_{H t}}{\bar{P}_{T t}}\right)^{\frac{\rho}{\rho-\gamma}}\right]^{-1} .
$$

Domestic markup fluctuations for the traded good reflect the presence of nominal rigidities and a variable demand elasticity. To separate out these two sources of markup fluctuations, it is convenient to define the desired domestic markup (i.e. the markup in the absence of nominal price rigidities) of a traded good firm as:

$$
\mu_{H t}(i)=\frac{\epsilon_{H t}(i)}{\epsilon_{H t}(i)-1}=\left[\gamma+\nu(1-\gamma) p_{H t}(i)^{\frac{1}{1-\gamma}} \bar{p}_{T t}^{\frac{\rho}{\gamma-\rho}}\right]^{-1},
$$

where the lower case variables denote relative prices (i.e., $p_{H t}(i)=\frac{P_{H t}(i)}{P_{H t}}$ and $\bar{p}_{T t}=\frac{\bar{P}_{T t}}{P_{H t}}$ ). For $\nu>0$, the elasticity of demand increases when $p_{H t}(i)$ increases and as a result a firm will lower its desired markup. In addition, a decrease in relative import prices $p_{F t}=\frac{P_{F t}}{P_{H t}}$ lowers $\bar{p}_{T t}$ (see equation 19), raising the elasticity of demand and inducing a firm to lower its desired markup. ${ }^{6}$

\footnotetext{
${ }^{5}$ For convenience, we have suppressed all of the state indices. In the household problem, we define $\xi_{t, t+1}$ to be the price in period $t$ of a claim that pays one unit of the home currency if the specified state occurs in period $t+1$. The corresponding element of $\psi_{t, t+1}$ equals $\xi_{t, t+1}$ divided by the probability that the specified state occurs.

6 This reasoning assumes that $\gamma>1>\rho$, which is true for our benchmark estimates. More specifically, we require $\frac{\nu \rho(\gamma-1)}{\gamma-\rho}>0$ in the neighborhood of non-stochastic steady state for the pricing decisions to be strategic complements according to Woodford (2003), who defines pricing decisions to be strategic complements if an increase in the prices charged for other goods increases a firm's own optimal price.
} 
Thus, a traded goods firm will change its desired price in response to changes in both domestic and foreign competition.

The first-order approximation of equation (23) can be written as:

$$
\hat{\pi}_{H t}=\beta E_{t} \hat{\pi}_{H t+1}+\kappa_{H}\left[(1-\Psi)\left(M C_{T t}-\hat{P}_{H t}\right)+\Psi \omega \frac{\epsilon_{T}}{\epsilon} \hat{p}_{F t}\right]
$$

where $\hat{\pi}_{H t}$ is domestic traded goods price inflation expressed as a log deviation from steady state and $\kappa_{H}=\frac{\left(1-\beta \theta_{H}\right)\left(1-\theta_{H}\right)}{\theta_{H}}$. The composite parameter $\kappa_{H}=\frac{\left(1-\beta \theta_{H}\right)\left(1-\theta_{H}\right)}{\theta_{H}}$ influences the sensitivity of inflation to marginal cost and depends on the degree of nominal rigidities.

The composite parameter $\Psi$ reflects variations in desired markups associated with competition from other firms. It can be related to the parameters governing the demand curve for good $i$ via:

$$
\Psi=\frac{\nu \mu}{1+\nu \mu}
$$

In the above, $\mu=\frac{1}{\gamma+(1-\gamma) \nu}$ denotes the economy's steady state markup. A higher value of $\nu$ increases $\Psi$, which implies that a firm's desired price is less sensitive to marginal cost and more sensitive to the prices of its competitors. Consequently, a higher value of $\nu$ is also associated with reduced sensitivity of non-traded goods inflation to real marginal cost. The sensitivity of domestic inflation to relative import prices also depends on the steady state elasticity of substitution between home and foreign goods $\left(\epsilon_{T}=\frac{\rho}{(\rho-\gamma)(1-\nu)}>0\right)$ relative to the steady state elasticity of two home brands $\left(\epsilon=\frac{1}{(1-\gamma)(1-\nu)}>0\right)$. In particular, a lower elasticity of substitution between home and foreign goods reduces the sensitivity of domestic traded goods inflation to foreign competition. Moreover, the degree of trade openness $(\omega)$ also influences the extent to which foreign competition influences domestic price inflation.

Under the assumption of LCP, domestic firms set prices for their goods in units of foreign currency according to Calvo contracts with constant probability $1-\theta_{H}^{*}$ of being able to reoptimize their prices. Firm $i$ sets its price, $P_{H t}^{*}(i)$, to maximize:

$$
E_{t} \sum_{j=0}^{\infty} \psi_{t+j} \theta_{H}^{* j}\left[e_{t+j} P_{H t}^{*}(i)-M C_{T t+j}\right] A_{H t+j}^{*}(i),
$$


taking the exchange rate $\left(e_{t+j}\right)$ denominated in units of home currency per units of foreign currency, $M C_{T t+j}$, and its demand schedule, $A_{H t+j}^{*}(i)$, as given. (We use a "*" to denote foreign variables.) The first-order condition from this problem is:

$$
E_{t} \sum_{j=0}^{\infty} \psi_{t+j} \theta_{H}^{* j}\left[1-\left(1-\frac{M C_{T t+j}}{e_{t+j} P_{H t}^{*}(i)}\right) \epsilon_{H t+j}^{*}(i)\right] e_{t+j} A_{H t+j}^{*}(i)=0,
$$

where the elasticity of demand for traded good $i$ in the foreign market is:

$$
\epsilon_{H t}^{*}(i)=\frac{1}{1-\gamma}\left[1-\nu\left(\frac{P_{H t}^{*}(i)}{P_{H t}^{*}}\right)^{\frac{1}{1-\gamma}}\left(\frac{P_{H t}^{*}}{\bar{P}_{T t}^{*}}\right)^{\frac{\rho}{\rho-\gamma}}\right]^{-1} .
$$

Both the variable demand elasticity and the fact that prices are sticky in local currency terms will influence the responsiveness of foreign import prices $\left(P_{H t}^{*}(i)\right)$ to movements in the exchange rate. A first-order approximation of equation (29) yields:

$$
\hat{\pi}_{H t}^{*}=\beta E_{t} \hat{\pi}_{H t+1}^{*}+\kappa_{H}^{*}\left[(1-\Psi)\left(\hat{M} C_{T t}-\hat{e}_{t}-\hat{P}_{H t}^{*}\right)+\Psi(1-\omega) \frac{\epsilon_{T}}{\epsilon} \hat{p}_{F t}^{*}\right],
$$

where $\hat{\pi}_{H t}^{*}$ denotes foreign import price inflation expressed as a log deviation from steady state and $\kappa_{H}^{*}=\frac{\left(1-\beta \theta_{H}^{*}\right)\left(1-\theta_{H}^{*}\right)}{\theta_{H}^{*}}$. From this expression, we can see that the sensitivity of foreign import prices to the exchange rate will be influenced by the degree of nominal rigidities through its effect on $\kappa_{H}^{*}$ and the responsiveness of a domestic firm's desired foreign price to the prices of its competitors through its effect on $\Psi$. Since in the foreign market a domestic firm competes with foreign tradable goods producers, foreign import price inflation depends on the price of the foreign tradable good relative to the domestic tradable good $\left(p_{F t}^{*}=\frac{P_{F t}^{*}}{P_{H t}^{*}}\right)$ Because a home exporter does not want its price to deviate too far from its foreign competitors, an exporter will reduce its desired markup in response to a shock that appreciates the exchange rate and increases its marginal cost. In this way, pass-through of exchange-rate changes to import prices can be incomplete even in the absence of nominal price rigidities.

A novel feature of either equations (26) or (31) is that they can be used to separately identify variations in markups associated with nominal rigidities (i.e., $\theta_{H}, \theta_{H}^{*}$ ) from variations in markups associated with the variable demand elasiticity (i.e., $\Psi$ ). Unfortunately, achieving such identification is not possible in closed economy models with both sticky prices and a 
Kimball-type aggregator or in open-economy variants such as Bouakez (2005). ${ }^{7}$ This lack of identification has made it difficult to estimate Kimball demand curves, and estimates such as in Bouakez (2005) are derived by holding the Calvo price setting parameter constant. Instead, we are able to jointly estimate these parameters, and in our empirical approach discussed below do so for $\Psi$ and $\theta_{F}$, the Calvo price setting parameter for foreign exporters. ${ }^{8}$

\subsubsection{Producer Currency Pricing}

For our second alternative, we assume that a traded goods firm practices producer currency pricing $(\mathrm{PCP})$. In this case, a firm sets one price for its good for the world market, $P_{H t}(i)$, in terms of their own currency. This price is set according to Calvo-style contracts with the probability $1-\theta_{H}$ of being able to re-optimize their price. Since the law of one price holds in this case, a firm's export price is given by

$$
P_{H t}^{*}(i)=\frac{P_{H t}(i)}{e_{t}}
$$

According to equation (32), holding domestic prices fixed, an exporter will change its price onefor-one with a given percentage change in the exchange rate so that pass-through of exchange rate changes to foreign import prices will be complete.

Under PCP, firm $i$ sets it price, $P_{H t}(i)$, to maximize:

$$
E_{t} \sum_{j=0}^{\infty} \psi_{t+j} \theta_{H}^{j}\left[P_{H t}(i)-M C_{T t+j}\right]\left(A_{H t+j}(i)+A_{H t+j}^{*}(i)\right),
$$

taking marginal cost as well as the home and foreign demand schedules as given. The first-order condition from this problem is:

$$
\begin{aligned}
& E_{t} \sum_{j=0}^{\infty} \psi_{t+j} \theta_{H}^{j}\left[\left(A_{H t+j}(i)+A_{H t+j}^{*}(i)\right)-\right. \\
& \left.\left(1-\frac{M C_{T t+j}}{P_{H t}(i)}\right)\left(\epsilon_{H t+j}(i) A_{H t}(i)+\epsilon_{H t+j}^{*}(i) A_{H t+j}^{*}(i)\right)\right]=0 .
\end{aligned}
$$

\footnotetext{
7 Our aggregator also has the attractive feature of implying similar behavior for the desired prices of international goods as the game-theoretic models of Atkeson and Burstein (2005) and Bodnar, Dumas, and Marston (2002). See the appendix of Gust, Leduc, and Vigfusson (2006) for a discussion.

8 See, Guerrieri, Gust, and López-Salido (2008), for an alternative application and estimation strategy that exploits the fact that these two sources of markup variations can be separately identified via equation (26).
} 
A first-order approximation of this equation yields:

$$
\left.\hat{\pi}_{H t}=\beta E_{t} \hat{\pi}_{H t+1}+\kappa_{H}\left[(1-\Psi)\left(M C_{T t}-\hat{P}_{H t}\right)+\Psi \omega(1-\omega) \frac{\epsilon_{T}}{\epsilon}\left(\hat{p}_{F t}+\hat{p}_{F t}^{*}\right)\right)\right] .
$$

\subsection{Intermediate Non-Traded Goods Production}

The producer of non-traded good $i$ is a monopolistically competitive firm, which sells its good to producers of the aggregate non-traded good. Firm $i$ in the non-traded sector utilizes capital and labor to produce its good according to:

$$
Y_{N t}(i)=Z_{N t} K_{t}(i)^{\alpha} L_{t}(i)^{1-\alpha},
$$

where $Z_{N t}$ is a shock to the level of technology in the non-traded sector. Intermediate good firms purchase capital and labor from the economy's households in perfectly competitive factor markets, and we assume that capital and labor are completely mobile within a country. Thus, all non-traded goods producers have identical marginal cost per unit of output, $M C_{N t}$.

We assume that a non-traded firm sets its price according to Calvo-style contracts with constant probability $1-\theta_{N}$ of being able to re-optimize its price. In choosing its price, $P_{N t}(i)$, a firm maximizes:

$$
E_{t} \sum_{j=0}^{\infty} \psi_{t+j} \theta_{N}^{j}\left[P_{N t}(i)-M C_{N t+j}\right] A_{N t+j}(i),
$$

taking $\psi_{t+j}, M C_{N t+j}$, and its demand schedule as given. The first-order condition from this problem is:

$$
E_{t} \sum_{j=0}^{\infty} \psi_{t+j} \theta_{N}^{j}\left[1-\left(1-\frac{M C_{N t+j}}{P_{N t}(i)}\right) \epsilon_{N t+j}(i)\right] A_{N t+j}(i)=0,
$$

where the elasticity of demand for non-traded good $i$ is:

$$
\epsilon_{N t}(i)=\frac{1}{1-\gamma}\left[1-\nu\left(\frac{P_{N t}(i)}{\bar{P}_{N t}}\right)^{\frac{1}{1-\gamma}}\right]^{-1} \text {. }
$$

A first-order approximation of equation (38) yields:

$$
\hat{\pi}_{N t}=\beta E_{t} \hat{\pi}_{N t+1}+\kappa_{N}(1-\Psi)\left(\hat{M} C_{N t}-\hat{P}_{N t}\right),
$$

where $\hat{\pi}_{N t}$ is non-traded goods price inflation expressed as a log deviation from steady state and

$\hat{M} C_{N t}-\hat{P}_{N t}$ represents real marginal cost in units of non-traded goods, and $\kappa_{N}=\frac{\left(1-\beta \theta_{N}\right)\left(1-\theta_{N}\right)}{\theta_{N}}$. 


\subsection{The Government and Monetary Policy}

Some of the final good is purchased by the government so that $A_{t}$ can be interpreted as total absorption:

$$
A_{t}=C_{t}+I_{t}+G_{t}
$$

We assume that government purchases $\left(G_{t}\right)$ follow an exogenous, stochastic process and do not directly affect the utility function of the representative household. The government's budget is balanced every period which implies that lump-sum taxes are equal to nominal government purchases. $^{9}$

We assume that monetary policy follows an interest rate rule:

$$
\hat{i}_{t}=\gamma_{\pi} \hat{\pi}_{t}+\gamma_{y} \hat{y}_{t}
$$

where the above variables are expressed in logarithmic deviation from steady state. Hence, $\hat{i}_{t}$ denotes the (gross) quarterly nominal interest rate expressed as a log-deviation from steady

state, and $\pi_{t}=\frac{P_{t}}{P_{t-1}}$ is the quarterly rate of inflation. The interest rate rule also includes the log deviation of output from potential output, where potential output is defined as the domestic economy's level of output in the absence of sticky prices.

\section{Method of Moments Estimation}

In this section we discuss our procedure for assigning values to the model's parameters. Our approach involves estimating key model parameters that influence exchange rate pass-through and the trade balance using a generalized method of moments procedure, while calibrating other parameters.

\footnotetext{
9 The assumption of a balanced budget is not restrictive given the Ricardian nature of the model, and the availability of lump-sum taxes.
} 


\subsection{Calibrated Parameter Values}

We solve our general equilibrium model by assigning numerical values to its parameters and log-linearizing the equations around the steady state. ${ }^{10}$ For simplicity, we choose the model parameters to be the same across countries so we only discuss the parameter values for the home country.

We calibrate the model at a quarterly frequency by setting $\beta=(1.03)^{-0.25}$ and $\delta=0.025$. The utility function parameter $\chi$ is set to 1, which implies a Frisch labor supply elasticity of 1 , while $\chi_{0}$ is chosen so that the steady state level of hours worked is normalized to unity. We choose a small value for the financial intermediation cost, $\phi_{b}=0.0001$, which is necessary to ensure that net foreign assets are stationary.

The Cobb-Douglas production function parameter $\alpha=0.4$ in both the traded and nontraded sectors. We set the elasticity of substitution between traded and non-traded goods $\left(\frac{1+\rho_{a}}{\rho_{a}}\right)$ to be 0.74 , based on the estimates of Mendoza (1991) for industrial countries. The share parameter $\phi$ was set equal to 0.2 , which implies that the non-traded good accounts for 58 percent of absorption, in line with U.S. data. Following Burstein, Neves, and Rebelo (2003), we choose $\eta=1$ so that the non-traded component of the retail price of the traded good is 50 percent. We set $\omega=0.25$ so that the economy's import share is about 10 percent.

For the degree of nominal rigidities for non-tradable prices and domestic tradable prices at home and abroad, we choose $\theta_{N}=\theta_{H}=\theta_{F}^{*}=0.75$, which implies that these prices are reoptimized once a year on average. ${ }^{11}$ These values are broadly consistent with the micro evidence of Nakamura and Steinsson (2007), who find a median duration of non-sale prices of 8-11 months using prices for both consumers and producer's finished goods. ${ }^{12}$ For our benchmark results,

\footnotetext{
10 To obtain the reduced-form solution of the model, we use the numerical algorithm of Anderson and Moore (1985), which provides an efficient implementation of the method proposed by Blanchard and Kahn (1980).

11 Although these parameters are separately identifiable in our model, we choose not to estimate them. Instead, we exploit this feature of our model and jointly estimate $\Psi$ with $\theta_{F}$, the foreign exporter's Calvo pricing parameter, to keep the focus of the paper on international price-setting behavior in the model.

12 The findings of Nakamura and Steinsson (2007) are also in line with earlier micro studies surveyed in Taylor (1999). In contrast, Bils and Klenow (2004) find a much higher frequency of price adjustment using micro data on consumer prices. The lower frequency of price changes in Nakamura and Steinsson (2007) largely reflects that they exclude temporary sales in measuring price changes, while Bils and Klenow (2004) include sales.
} 
we assume that the a foreign exporter sets its price in local currency and a home exporter sets its price in producer currency based on the empirical work of Gopinath and Rigobon (2006) and Goldberg and Tille (2006) for the United States. In addition, in our results we compare this setup to symmetric environments of local currency pricing and producer currency pricing. For the monetary policy rule, following Taylor (1993), we set $\gamma_{\pi}=1.5$ and $\gamma_{y}=0.5 / 4$.

Our solution algorithm also requires us to specify the evolutionary process of the shocks, $\left\{Z_{N t}, Z_{T t}, G_{t}, Z_{N t}^{*}, Z_{T t}^{*}, G_{t}^{*}\right\}$. To cut down on the number of shock processes that we need to estimate, we assume that there is just one aggregate technology shock in each economy (i.e., $Z_{t}=Z_{N t}=Z_{T t}$ and $\left.Z_{t}^{*}=Z_{N t}^{*}=Z_{T t}^{*}\right)$. We specify that the technology and government spending shocks in both countries follow a first-order autoregressive process with each shock independent from another. Thus, both the aggregate technology shock and government spending shock are uncorrelated across countries.

For government spending, we set the autoregressive coefficient, $\rho_{g}=0.98$, and the standard deviation of the shock, $\sigma_{g}=0.016$. These values are consistent with the regression estimates of Erceg, Guerrieri, and Gust (2005), who use quarterly NIPA data on government consumption and investment from 1958-2002. We set the steady state ratio of government spending to output $(g)$ in each economy to 0.18 .

\subsection{Estimation Procedure}

We set the parameters for the technology shock, $\rho_{Z}$, and $\sigma_{Z}$, the average contract duration of foreign export prices, $\theta_{F}$, and the demand curve parameters $\rho$ and $\nu$ as part of a moment matching exercise. Our estimation procedure is to choose the vector of model parameters, $\Gamma=\left[\theta_{F}, \nu, \rho, \sigma_{Z}, \rho_{Z}\right]^{\prime}$, to minimize:

$$
\left(\hat{v}_{t}-f(\Gamma)\right) \hat{V}_{T}^{-1}\left(\hat{v}_{t}-f(\Gamma)\right)^{\prime}
$$

where $\hat{v}_{t}$ is a vector of point estimates of moments from U.S. data and $\hat{V}_{T}^{-1}$ is a matrix whose diagonal contains the (asymptotic) estimates of the underlying sampling variance for these moments and off-diagonal elements are zero. We now describe our choice of moments. 
Since the parameters $\theta_{F}$ and $\nu$ have important implications for the degree of exchange rate pass-through to the home country's import prices, we use a measure of pass-through to estimate these parameters. To evaluate the sensitivity of import prices to exchange rate movements at the dock, we use the following statistic:

$$
\beta\left(p_{F}, q\right)=\frac{\rho\left(p_{F}, q\right) \sigma_{p_{F}}}{\sigma_{q}},
$$

where $p_{F}=\frac{P_{F}}{P}$ denotes the relative import price of the home country, and $q=\frac{e P^{*}}{P}$ is the real exchange rate. This statistic takes into account the correlation between the two series $\rho\left(p_{F}, q\right)$ as well as the volatility of import prices $\sigma_{p_{F}}$ relative to exchange rate volatility $\sigma_{q}$ and can be derived as the estimate from a univariate least squares regression of the real exchange rate on the relative import price. To separately identify variations in markups due to local currency pricing (i.e., $\theta_{F}$ ) and variations due to the variable demand elasticity (i.e., $\nu$ ), we compute $\beta\left(p_{F}, q\right)$ at both a low and a high frequency. Intuitively, this more complete description of pass-through dynamics allows us to identify these two sources of incomplete pass-through to import prices at the dock, because over longer time horizons, the nominal rigidities become less important for accounting for low exchange rate pass-through.

The first column of Table 1 reports $\beta\left(p_{F}, q\right)$ based on U.S. data at periodicities between 2 and 8 quarters (i.e., high frequencies) and between 20 and 40 quarters (i.e., low frequencies) using the band pass filter of Baxter and King (1995). ${ }^{13}$ U.S. import prices are less sensitive to real exchange rate movements at high frequencies than at low frequencies: $\beta^{H}\left(p_{F}, q\right)=0.29$ at periodicities between 2 and 8 quarters and $\beta^{L}\left(p_{F}, q\right)=0.58$ at periodicities between 20 and 40 quarters. $^{14}$ (We use superscripts to denote the frequency of the statistic so that an "L" indicates low frequencies, "H" indicates high frequencies, and "BC" indicates business cycle frequencies.)

\footnotetext{
${ }^{13}$ We use quarterly data over the sample period, 1973:Q1-2007:Q3. All of our data are from the U.S. National Income and Product Accounts except for the real exchange rate. For this series, we use the Federal Reserve's real effective exchange rate. Our import price series excludes fuel prices, and we use the PCE deflator excluding food and energy as our measure of consumer price inflation.

14 Our results that import prices are less sensitive in the short run than long run to the exchange rate is consistent with a large empirical literature (e.g., Campa and Goldberg (2005) and Marazzi and Sheets (2007)) that estimates pass-through to import prices at the dock.
} 
Another relevant statistic that we use to estimate our model is:

$$
\beta(\pi, q)=\frac{\rho(\pi, q) \sigma_{\pi}}{\sigma_{q}}
$$

where $\pi$ denotes consumer price inflation. This statistic measures the sensitivity of consumer price inflation to exchange rate movements and is influenced by $\theta_{F}$ and $\nu$, which have important effects on exchange rate pass-through to wholesale import prices. It is also influenced by $\eta$, which determines the size of the distribution sector and affects the extent of pass-through to retail import prices. The last entry in the first column of Table 2 shows that at business cycle frequencies (i.e., periodicities of 8 to 32 quarters) $\beta(\pi, q)$ is quite low, less than 2 percent, consistent with the evidence presented in McCallum and Nelson (2000).

In our analysis, an important determinant of the response of the trade balance to shocks is the steady state elasticity of substitution between home and foreign goods, $\epsilon_{T}$, which in turn influences the responsiveness of real trade flows to relative trade prices (i.e., the the trade price elasticities). We estimate the demand curve parameter, $\rho$, which determines $\epsilon_{T}$, based on the moment, $\beta\left(\frac{A_{F}}{A}, p_{F}\right)$, where $\frac{A_{F}}{A}$ denotes real imports scaled by real domestic absorption, $A_{t}$. This statistic measures the responsiveness of real imports to changes in the relative price of imports, while controlling for changes in activity (i.e., absorption). As is well known, there is a debate in the empirical literature regarding the size of the trade price elasticity. Approaches emphasizing the behavior of trade at business cycle frequencies tend to find relatively low estimates; studies of trade reforms highlighting the response of trade over longer time spans typically find much higher values. ${ }^{15}$ To estimate $\epsilon_{T}$, we included $\beta\left(\frac{A_{F}}{A}, p_{F}\right)$ at only a relatively low frequency (i.e., periodicities between 20 and 40 quarters) in our estimation procedure, though we still use the higher frequency moment to evaluate the model's fit. The first column of Table 1 shows that based on U.S. data $\beta^{L}\left(\frac{A_{F}}{A}, p_{F}\right)=-0.61$ for periodicities between 20 and 40 quarters, and this statistic is even lower at a higher frequency. ${ }^{16}$

The remaining two parameters that we estimate are the standard deviation, $\sigma_{Z}$, and the first-order autocorrelation, $\rho_{Z}$ of the aggregate technology shock. To estimate these parameters,

\footnotetext{
15 For a discussion of the estimates of trade price elasticities, see Engel and Wang (2007) and Ruhl (2005) and the references therein.

16 We use NIPA data to apply standard chain-aggregation routines to construct the real absorption series.
} 
we use the standard deviation of GDP, $\sigma^{B C}(Y)$, and the first-order autocorrelation of GDP, $\rho^{B C}\left(Y, Y_{-1}\right)$, computed at business cycle frequencies. The values of these statistics are reported in Table 2.

We condition our estimates on a value of the demand curve parameter $\gamma$ that implies a steady state markup of 20 percent (i.e., $\mu=1.2$ ). Since $\mu=\frac{\epsilon}{\epsilon-1}$, the steady state elasticity of substitution between home traded or non-traded goods in the economy $(\epsilon)$ is six. Finally, we note that the three demand curve parameters, $\{\rho, \gamma, \nu\}$, uniquely determine $\left\{\epsilon_{T}, \mu, \Psi\right\}$. In our discussion, we focus on the estimates of $\left\{\epsilon_{T}, \mu, \Psi\right\}$, since they are more economically meaningful.

\subsection{Estimated Parameters}

Table 3 reports the results from our estimation procedure. Our estimated value of $\Psi$ is 0.85 , which implies a demand elasticity that is far from constant (i.e., $\Psi=0$ ) so that firms vary their desired markups considerably in response to changes in competition. In particular, a firm will raise its desired price only 0.15 percent in response to a 1 percent idiosyncratic change in its marginal cost, holding all else equal, since it lowers its desired markup in order to keep its desired price relatively constant compared to those of its competitors. Our estimate of $\Psi$ is higher than the 0.73 estimate of Guerrieri, Gust, and López-Salido (2008) and 0.67 estimate of Dossche, Heylen, and den Poel (2007), but considerably lower than the 0.96 estimate of Bouakez (2005) and 0.98 calibrated value of Chari, Kehoe, and McGrattan (2000). ${ }^{17}$

We estimate $\theta_{F}=0.5$, which implies that foreign exporters re-optimize their prices every two quarters on average. This estimate is lower than the 11 month average duration of price changes for U.S. import prices found by Gopinath and Rigobon (2006). However, as discussed below, our results regarding the relationship between the nominal trade balance and exchange rate pass-through are robust to higher values of $\theta_{F}$.

\footnotetext{
17 Our estimate of $\Psi$ also has important implications for how much a firm's demand elasticity varies. For our estimated value of $\Psi$, a 2 percent increase in the desired price of good $i$ reduces the relative demand for good $i$ by 16 percent and 2.3 percent increase reduces demand by 19 percent. In contrast, the value of $\Psi=0.98$ used by Chari, Kehoe, and McGrattan (2000) implies that a 2 (2.3) percent increase in a firm's price lead to a 78 (100) percent fall in demand. Thus, relative to their calibration, our estimated demand curve appears quite reasonable.
} 
The estimated value of the elasticity of substitution between home and foreign goods, $\epsilon_{T}$ is 0.8, which is similar to that estimated by Corsetti, Dedola, and Leduc (2008b) in a model with distribution services. It is interesting to note that our estimate remains near unity even though we used information at relatively long horizons (5 to 10 years) to estimate this parameter. However, since estimates from the literature following permanent changes in tariffs are typically much higher - ranging from 6 to 15 - we also consider the sensitivity of our results to higher values for $\epsilon_{T}$ as well as allowing for an alternative specification in which the long-run elasticity of substitution between home and foreign goods can differ from the short-run elasticity.

\section{Results}

In this section, we evaluate the empirical fit of our benchmark model and use it to examine how the trade balance responds to different shocks in high and low pass-through environments. We also examine the sensitivity of our results to different mechanisms for inducing incomplete exchange rate pass-through to import prices, alternative monetary policy rules, and alternative assumptions regarding the elasticity of substitution between home and foreign goods.

\subsection{Empirical Fit of the Benchmark Economy}

Table 1 presents some key trade statistics for the United States at high and low frequencies and the corresponding predictions from our estimated model under the column labeled "Benchmark". The model matches the measure of pass-through, $\beta\left(p_{F}, q\right)$, at both low and high frequencies. Our assumption that domestic exporters set prices in producer currency implies, as in the data, that U.S. export prices denominated in dollars are insensitive to exchange rate movements. (Alternatively, there is high pass-through of exchange rate changes to foreigndenominated import prices of U.S. goods.) Our estimation procedure performs reasonably well in matching the responsiveness of U.S. imports to changes in relative import prices at a low frequency. At high frequency, the model predicts a higher point estimate for this moment, though once one takes into account the sampling uncertainty in the data, the departure is not 
large. Overall, we view our model as being consistent with some key empirical correlations of trade prices and quantities.

We also report the business cycle properties of the benchmark model in Table 2, which shows that the benchmark model accounts for roughly 45 percent of the volatility of the nominal trade balance, even though in order to keep the analysis tractable we have abstracted from the fact that trade is more intensive in durable than nondurable goods. ${ }^{18}$ In the benchmark model, the terms of trade are also less volatile than the real exchange rate, reflecting in part movements in the relative price of non-traded goods (see Corsetti, Dedola, and Leduc (2008b) for a discussion). Moreover, a worsening of the terms of trade is associated with a depreciation of the real exchange rate, an empirical feature emphasized by Obstfeld and Rogoff (2000a). However, the correlation in the model is more pronounced than in the data. Finally, a standard shortcoming of our benchmark model is the relatively low volatility of the real exchange rate, which is only 1.6 times as volatile as output.

\subsection{The Relationship Between Pass-Through and the Trade Balance}

To what extent does a low pass-through environment affect the response of the nominal trade balance to shocks hitting the economy? To address this question, we consider the effects of various shocks on the trade balance for three alternatives assumptions that affect the degree of exchange rate pass-through at the border. Our first alternative is the benchmark version of the model in which pass-through is asymmetric: low import price pass-through in the home country and high import price pass-through in the foreign country. This asymmetry reflects that foreign exporters price to market and home exporters engage in producer currency pricing. We compare this benchmark scenario to the case in which pass-through is low in both countries labeled "Low ERPT", as both home and foreign producers price to market, and to the case in

\footnotetext{
18 Introducing this feature would tend to increase the variability of trade variables in the model. See, Boileau (1999), Engel and Wang (2007) and Erceg, Guerrieri, and Gust (2008) for a discussion. Our results regarding the relationship between import price pass-through and the trade balance are robust to the trade specification used in Erceg, Guerrieri, and Gust (2008) in which investment goods are more trade intensive than consumption goods. To keep the model's pricing behavior relatively tractable, we choose to follow Backus, Kehoe, and Kydland (1994) and work with our absorption-based trade specification in which the shares of imports in final consumption and investment goods are the same.
} 
which pass-through is high in both countries labeled "High ERPT", as both home and foreign producers engage in producer currency pricing.

Before discussing the effects of various shocks on the trade balance for these scenarios, it is helpful to first make a few comments about their empirical relevance. As shown in Table 1 under the column "Low ERPT" a symmetric framework of local currency pricing and pricing to market implies that export prices are overly sensitive to movements in the real exchange rate relative to the data. Moreover, as emphasized by Obstfeld and Rogoff (2000a) in their critique of local currency pricing, Table 2 shows that an exchange rate depreciation is also associated with a counterfactual terms of trade improvement in this case. Finally, in the scenario with both home and foreign producers engaging in producer currency pricing (not shown), the model implies that import prices are overly responsive to exchange rate movements. Although these two cases do not match the data as well as our benchmark case, they are useful for illustrating the differences that arise in an environment in which pass-through at the border is high as opposed to low.

Figure 1 shows the effects of a decrease in home government spending on the nominal trade balance for the benchmark scenario (the dotted blue line). ${ }^{19} \mathrm{~A}$ fall in government spending directly lowers domestic absorption (i.e., $C_{t}+I_{t}+G_{t}$ ) as well as indirectly through investment, as a decline in hours worked reduces the marginal product of capital. The real exchange rate depreciates and the terms of trade deteriorate after the shock. Both the decline in absorption and the real exchange rate depreciation contribute to improvements in the real and nominal trade balance. Over a longer horizon, the real exchange rate begins to appreciate and both the real and nominal trade balance gradually returns to their steady state values.

Figure 1 also shows the effects of the government spending shock for the "Low ERPT" scenario (the solid black line) and the "High ERPT" (the dashed red line). The degree of pass-through does not bring about substantial differences in the response of the nominal trade balance. The largest difference between these two scenarios occurs initially, as the improvement in the nominal trade (as a share of GDP) is 0.65 percentage point in the "High ERPT" scenario

\footnotetext{
19 To facilitate the comparison across different shocks, the shock has been scaled to deliver a 1 percent depreciation of the real exchange rate 4 quarters after the shock in the "Low ERPT" scenario.
} 
and 0.55 percentage point in the "Low ERPT". Over longer horizons, the differences are smaller and there is actually more adjustment in the low pass-through environment.

These small differences for the two extreme scenarios mainly reflect two opposing forces. On the one hand, low pass-through tends to mute the sensitivity of the real economy and domestic absorption to exchange rate changes. This effect is most visible initially in which there is a much larger fall in absorption in the high pass-through scenario than in the low pass-through scenario. This larger fall in absorption accounts for the greater initial trade balance improvement in the "High ERPT" scenario. On the other hand, a low pass-through environment amplifies the real exchange rate depreciation following the shock and this effect tends to contribute to greater nominal adjustment, helping account for the slightly higher adjustment of the trade balance over longer horizons in the low pass-through scenario.

Table 5 shows the response of the nominal trade balance to a monetary expansion and the aggregate technology shock in addition to the government spending shock discussed earlier. ${ }^{20}$ The insensitivity of the trade balance to alternative pass-through assumptions does not appear to be shock specific. While the monetary shock, for example, can induce very different real trade responses in a low pass-through environment than a high pass-through environment, there is very little difference in the response of the nominal trade balance for each of these shocks.

\subsubsection{Comparison to Obstfeld and Rogoff (2004)}

In a series of influential papers, Obstfeld and Rogoff (2000b) and Obstfeld and Rogoff (2004) have argued that the turnaround of the U.S. trade deficit could have dramatic consequences for the real exchange rate and the U.S. economy more broadly. Their analyses were based on simple but fairly representative open-economy models in which there is full pass-through of exchange rate changes to import prices. Although they never formal incorporate features into their model consistent with incomplete pass-through, they conjecture that the size of the dollar

\footnotetext{
20 To facilitate the comparison across scenarios and different shocks, each shock has been scaled to deliver a 1 percent depreciation of the real exchange rate 4 quarters after the shock in the "Low ERPT" scenarios. For the monetary shock, we add a shock to equation (42) that is a first-order autoregressive process with a coefficient equal to 0.8 .
} 
depreciation would be twice as large in an economy in which pass-through is only 50 percent.

Can we reconcile our results with this conjecture? Our results suggest that nominal adjustment in a low pass-through and high pass-through environment is similar for a given-sized shock. Thus, to reduce the trade deficit by 1 percentage point, the magnitude of a particular shock would be comparable in a high and low pass-through environment. However, the underlying forces that bring about nominal adjustment are very different. In particular, a low pass-through environment is associated with greater movements in the nominal exchange rate, and thus, our results are broadly consistent with the OR conjecture. To see this, consider the government spending shock in Table 5. In this case, for a 1 percentage point improvement in the trade balance to occur after 4 quarters, the real exchange rate needs to depreciate slightly more than 1 percent in the "High ERPT" scenario. In comparison, the real exchange rate must depreciate about 2 percent in the "Low ERPT" scenario to induce the same amount of nominal adjustment.

\subsubsection{Sources of Pass-Through and External Adjustment}

Our benchmark model encompasses two different sources that account for incomplete passthrough at the dock: local currency pricing and a variable demand elasticity. Table 1 documents that abstracting from either variable demand elasticities (VES), shown by the column labeled "LCP/CES Demand", or from local currency pricing, shown by the column labeled "No LCP/VES Demand", implies that import price pass-through at both high and low frequencies is too high high relative to observed pass-through. ${ }^{21}$ Still, a natural question to ask is whether our results regarding the relationship between pass-through at the dock and the trade balance is robust to alternative calibrations of these two sources of low pass-through. Table 6 shows the trade balance response following a government spending shock for local currency pricing with CES demand curves (labeled "LCP/CES Demand") and no local currency pricing with

\footnotetext{
${ }^{21}$ In these alternatives, we did not re-estimate the model. If, instead, we re-estimate the model in the "LCP/CES Demand" case, the average contract duration rises to 5 quarters. This re-estimated model is able to match the high frequency responsiveness of import prices to the exchange rate but still implies too much pass-through at lower frequencies.
} 
VES demand curves (labeled "No LCP/VES Demand"). In addition, we also consider an alternative with local currency pricing in which the average contract duration is four quarters (labeled "4-qtr. LCP/VES Demand") instead of two quarters to be consistent with the estimates of Gopinath and Rigobon (2006). As shown there, the nominal trade balance response in the "Low ERPT" scenario is roughly equivalent to the "High ERPT" scenario, regardless of whether low pass-through is accounted for mainly by local currency pricing or variable demand elasticities.

A third source of incomplete pass-through is the presence of distribution services intensive in local goods, which mutes the responsiveness of the retail price of imports to exchange rate changes. To highlight the role of distribution services, Table 6 allows us to compare the benchmark scenario $(\eta=1)$ to the case of a smaller distribution sector $(\eta=0.5) .{ }^{22}$ This comparison suggests that lower pass-through to retail import prices via a larger distribution sector is associated with less trade adjustment than when there is the high pass-through to retail import prices; however, the difference is small. For instance, the nominal trade balance in the benchmark case with low pass-through at the dock (labeled Benchmark - Low ERPT) increases 0.42 percentage point 4 quarters after a government spending shock, and 0.44 percentage point when the distribution sector is smaller and pass-through to retail import prices is higher.

\subsubsection{Decomposition of the Nominal Trade Balance}

Our main finding is that the extent of pass-through does not significantly alter the response of the nominal trade balance to shocks. However, the forces underlying nominal trade adjustment can be very different in a high and low pass-through environment. To understand this result better, it is instructive to use a first-order approximation to decompose the movements in the nominal trade balance:

$$
t b_{t}=\bar{m}\left(\hat{A}_{H t}^{*}-\hat{t o t}_{t}-\hat{A}_{F t}\right)
$$

\footnotetext{
${ }^{22}$ In the experiment with $\eta=0.5$, we increased $\phi$ so that the the economy's trade share and relative size of the non-traded sector remained the same as in our benchmark.
} 
where $t b_{t}$ is the ratio of the nominal trade balance to nominal output, and $\bar{m}$ denotes the steady state ratio of nominal imports to nominal output. Also, tot $t_{t}=\hat{p}_{F t}-\hat{p}_{H t}^{*}-\hat{q}_{t}$ denotes the log deviation of the terms of trade from steady state defined using $\hat{p}_{H t}^{*}$, the home export price in foreign currency units relative to the foreign consumer price deflator and $q_{t}$, the real exchange rate. We can express real imports as:

$$
\hat{A}_{F t}=-\epsilon_{T} \hat{p}_{F t}+\hat{A}_{t}+\varphi_{t}
$$

and define an analogous expression for real exports. In equation $(44), \varphi_{t}=\left(\epsilon_{T}-\frac{1+\rho_{a}}{\rho_{a}}\right) \hat{p}_{T t}$, where $\hat{p}_{T t}$ denotes the wholesale price of the traded good relative to the consumer price level so that in general real imports directly reflect changes in the price of traded goods relative to non-traded goods.

Substituting in the expressions for real exports, imports, and the terms of trade, movements in the trade balance can be decomposed as:

$$
t b_{t}=\bar{m}\left[\epsilon_{T}\left(\hat{p}_{F t}-\hat{p}_{H t}^{*}\right)-\left(\hat{p}_{F t}-\hat{p}_{H t}^{*}-q_{t}\right)+\hat{A}_{t}^{*}-\hat{A}_{t}+\varphi_{t}-\varphi_{t}^{*}\right]
$$

Equation (45) highlights the critical role that the elasticity of substitution $\epsilon_{T}$ plays in our analysis. For the benchmark version of our model, $\varphi_{t} \approx 0$ and $\varphi_{t}^{*} \approx 0$ because $\epsilon_{T} \approx \frac{1+\rho_{a}}{\rho_{a}}$. Accordingly, changes in the relative price of tradables to non-tradables only have a small direct impact on the nominal trade balance. More notably, with $\epsilon_{T}<1$, as implied by our benchmark estimate, a given amount of real exchange rate depreciation will be associated with more trade adjustment in the "Low ERPT" scenario than in the "High ERPT" scenario, holding domestic and foreign absorption constant. This result reflects that low pass-through limits the increase in $p_{F t}-p_{H t}^{*}$ associated with the depreciation, which translates into a smaller terms of trade deterioration or even a terms of trade improvement if pass-through is low enough. With $\epsilon_{T}<1$, the effect of low pass-through on movements in the terms of trade outweighs the effect that low pass-through has on real trade adjustment via changes in relative prices, $p_{F t}-p_{H t}^{*}$. If $\epsilon_{T}>1$, however, the relative price effect on real trade dominates the terms of trade effect and we get the opposite result: holding home and foreign absorption constant, a given real depreciation would induce more adjustment in the "High ERPT" scenario. 


\subsection{Sensitivity to the Trade Price Elasticity}

To illustrate the importance of $\epsilon_{T}$, Figure 2 shows the effects of the government spending shock for $\epsilon_{T}=8$. Such a value is within the range of estimates coming from studies of trade liberalizations but well above our benchmark estimate. In this case, there is much less nominal adjustment in the "Low ERPT" scenario than the "High ERPT" scenario, reflecting that incomplete pass-through limits expenditure switching effects associated with movements in relative trade prices and reduces the sensitivity of absorption to exchange rate changes. The nominal trade balance rises about 1 percentage point on impact in the low pass-through world compared to the 2.5 percentage points increase in the high pass-through world.

However, as shown in Table 1 under the column labeled "High Elasticity", such a high elasticity of substitution between home and foreign goods implies that real imports are overly sensitive to movements in import prices both in the short and long run. Moreover, Table 2 shows that the volatility of the real exchange rate and terms of trade are much lower than for the benchmark estimates and relative to the data.

To address the concerns, a number of authors such as Ruhl (2005) and Ramanarayanan (2007) have developed micro-founded frictions that allow for a low substitutability of home and foreign goods in the short run and high substitutability in the long run. To capture such frictions, we follow Erceg, Guerrieri, and Gust (2006) and Engel and Wang (2007) and assume that there are costs for adjusting imports. Since incorporating these adjustment costs with a Kimball-type aggregator considerably complicates the analysis, we abstract from variations in desired markups (i.e., $\nu=\Psi=0$ ) as a source of low pass-through to import prices and specify that the aggregate traded good in the home economy is produced via:

$$
A_{T t}=\left[(1-\omega) A_{H t}^{\frac{\gamma}{\rho}}+\omega\left(\varphi_{t} A_{F t}\right)^{\frac{\gamma}{\rho}}\right]^{\frac{\rho}{\gamma}} .
$$

In equation (46), $A_{H t}$ and $A_{F t}$ are themselves aggregates of the individual domestic and foreign goods given by $A_{H t}=\left(\int_{0}^{1} A_{H t}(i)^{\gamma} d i\right)^{\frac{1}{\gamma}}$ and $A_{F t}=\left(\int_{0}^{1} A_{F t}(i)^{\gamma} d i\right)^{\frac{1}{\gamma}}$. Also, $\varphi_{t}$ is a quadratic 
adjustment cost for changing the proportion of imported to domestic goods:

$$
\varphi_{t}=\left[1-\frac{\varphi}{2}\left(\frac{\frac{A_{F t}}{A_{H t}}}{\frac{A_{F t-1}}{A_{H t-1}}}-1\right)^{2}\right] .
$$

With this specification, the long-run elasticity of substitution between home and foreign goods is given by $\epsilon_{T}=\frac{\rho}{\rho-\gamma}$, while the elasticity of substitution in the short or medium run is influenced by the adjustment cost parameter, $\varphi$.

To assess the implications of the model with adjustment costs, we chose $\varphi, \rho_{Z}$ and $\sigma_{Z}$ to match the moments used to measure pass-through, the responsiveness of U.S. imports to import prices, and output volatility and persistence. Since we abstract from the variable demand elasticity, we increase the average contract duration of foreign export prices from our benchmark estimate of 2 quarters $\left(\theta_{F}=0.5\right)$ to 4 quarters $\left(\theta_{F}=0.75\right)$. Finally, we set $\epsilon_{T}=8$ and choose the remaining parameter values to be the same as in the benchmark case.

Tables 1 and 2 under the column labeled "Adjust. Cost" shows that this model fits the data reasonably well. In particular, the model matches the responsiveness of U.S. imports to import prices at both high and low frequencies and implies somewhat greater exchange rate volatility than the benchmark case. The main shortcoming of the adjustment cost model is that it implies too much pass-through at longer horizons, which is not surprising, since we have abstracted from variations in desired markups.

Figure 3 shows the response of the trade balance to the government spending shock for the model with adjustment costs on trade. The nominal trade balance is roughly the same in the "Low ERPT" and "High ERPT" scenarios, reflecting that the adjustment costs imply a much lower effective elasticity of substitution between home and foreign goods at relevant horizons than $\epsilon_{T}=8$.

\subsection{Sensitivity to the Monetary Policy Rule}

Because the endogenous reaction of monetary policy can affect the transmission of shocks to the real exchange rate, the terms of trade, and absorption, it can impact the response of the trade balance in high and low pass-through environments. To assess the sensitivity of our results to 
alternative monetary policy rules, we first consider an interest-rate rule that puts some weight on exchange-rate stabilization. In this case, we modify the central bank's policy rule as follows:

$$
\hat{\imath}_{t}=\gamma_{\pi} \hat{\pi}_{t}+\gamma_{y} \hat{y}_{t}+\gamma_{e} \Delta \widehat{e}_{t}
$$

where $\Delta \widehat{e}_{t}$ refers to the log-change of the nominal exchange rate. There is little evidence that the Federal Reserve puts weight on the exchange rate in its reaction function. Still, Lubik and Schorfheide (2007) find evidence that a number of central banks such as the Bank of Canada and the Bank of England respond to exchange rate movements. We set $\gamma_{e}=0.5$, which is somewhat

higher than their point estimates, and used our benchmark model to evaluate the sensitivity to this change in the monetary policy rule. Table 7 shows that following a decrease in government spending, the response of the nominal trade balance is similar in the "Low ERPT" and "High ERPT" scenarios. More generally, Table 7 suggests that monetary policy is not the principle driver of our main results. In particular, when we consider a world economy with flexible prices, we continue to find little change in the responsiveness of the nominal trade balance for different pass-through environments.

\section{Conclusion}

In this paper, we developed an open economy DGE model with incomplete exchange rate passthrough to trade prices. We used this model to look intensively at the relationship between exchange rate pass-through and external adjustment.

An important implication of a low pass-through world is that real economic variables including absorption and real exports and imports — tend to respond less to shocks. This reflects the fact that with low pass-through foreign exporters absorb a portion of the shock into their margins. This tends to attenuate adjustment of the nominal trade balance. However, the exchange rate tends to move more in response to shocks in a low pass-through environment, which induces greater nominal adjustment. For reasonable values of the elasticity of substitution between home and foreign goods, these two effects offset, and the amount of nominal adjustment 
is largely independent of the extent of exchange-rate pass-through. Thus, to reduce the trade deficit by 1 percentage point, the magnitude of a particular shock would be comparable in a high and low pass-through environment. 


\section{References}

Anderson, G. and G. Moore (1985). A Linear Algebraic Procedure for Solving Linear Perfect Foresight Models. Economic Letters 17, 247-52.

Atkeson, A. and A. Burstein (2005). Trade Costs, Pricing to Market, and International Relative Prices. University of California at Los Angeles, mimeo.

Backus, D., E. Henriksen, F. Lambert, and C. Telmer (2006). Current Account Fact and Fiction. New York University, mimeo.

Backus, D. K., P. J. Kehoe, and F. E. Kydland (1994). Dynamics of the Trade Balance and the Terms of Trade: The J-Curve? American Economic Review 84, 84-103.

Baxter, M. and R. G. King (1995). Measuring Business-cycles: Approximate Band-Pass Filters for Economic Time Series. National Bureau of Economic Research Working Paper 5022 .

Bergin, P. and R. Feenstra (2001). Pricing-to-Market, Staggered Contracts, and Real Exchange Rate Persistence. Journal of International Economics 54, 333-59.

Betts, C. and M. Devereux (1999). The International Effects of Monetary and Fiscal Policy in a Two-Country Model. Discussion paper no. 99-10, University of British Columbia.

Bils, M. and P. Klenow (2004). Some Evidence on the Importance of Sticky Prices. Journal of Political Economy 112, 947-985.

BIS (2005). 75th Annual Report. Basel, Switzerland: Bank for International Settlements.

Blanchard, O., F. Giavazzi, and F. Sa (2004). The U.S. Current Account and the Dollar. National Bureau of Economic Research Working Paper 11137.

Blanchard, O. and C. Kahn (1980). The Solution of Linear Difference Models under Rational Expectations. Econometrica 48, 1305-1311.

Bodnar, G., B. Dumas, and R. Marston (2002). Pass Through and Exposure. Journal of Finance 57, 199-231.

Boileau, M. (1999). Trade in Capital Goods and the Volatility of Net Exports and the Terms of Trade. Journal of International Economics 48, 347-365.

Bouakez, H. (2005). Nominal Rigidity, Desired Markup Variations, and Real Exchange Rate Persistence. Journal of International Economics 66, 49-74.

Burstein, A. T., J. Neves, and S. Rebelo (2003). Distribution Costs and Real Exchange Rate Dynamics During Exchange-Rate-Based Stabilizations. Journal of Monetary Economics 50, 1189-1214.

Caballero, R. J., E. Fahri, and P.-O. Gourinchas (2006). An Equilibrium Model of "Global Imbalances" and Low Interest Rates. National Bureau of Economic Research Working Paper 11996. 
Campa, J. and L. Goldberg (2005). Exchange Rate Pass-Through into Import Prices. Review of Economics and Statistics 87, 679-690.

Chari, V. V., P. J. Kehoe, and E. R. McGrattan (2000). Sticky Price Models of the Business Cycle: Can the Contract Multiplier Solve the Persistence Problem? Econometrica 68(5), $1151-1179$.

Chari, V. V., P. J. Kehoe, and E. R. McGrattan (2002). Can Sticky Prices Generate Volatile and Persistent Real Exchange Rates? Review of Economic Studies 69, 533-563.

Corsetti, G., L. Dedola, and S. Leduc (2008a). DSGE Models of High Exchange-Rate Volatility and Low Pass-Through. Forthcoming.

Corsetti, G., L. Dedola, and S. Leduc (2008b). International Risk Sharing and the Transmission of Productivity Shocks. Review of Economic Studies 75, 443-473.

Dossche, M., F. Heylen, and D. V. den Poel (2007). The Kinked Demand Curve and Price Rigidity: Evidence from Scanner Data. Mimeo, National Bank of Belgium.

Dotsey, M. and R. King (2005). Implications of State-Dependent Pricing for Dynamic Macroeconomic Models. Journal of Monetary Economics 52, 213-42.

Edwards, S. (2005). Is the U.S. Current Account Deficit Sustainable? And, If Not, How Costly is Adjustment Likely to Be? National Bureau of Economic Research Working Paper 11541.

Eichenbaum, M. and J. D. Fischer (2007). Estimating the Frequency of Price Re-Optimization in Calvo-style Models. Journal of Monetary Economics. Forthcoming.

Engel, C. and J. H. Rogers (2006). The US Current Account Deficit and the Expected Share of World Output. Journal of Monetary Economics 53, 1063-1093.

Engel, C. and J. Wang (2007). International Trade in Durable Goods: Understanding Volatility, Cyclicality, and Elasticities. Federal Reserve Bank of Dallas Globalization and Monetary Policy Institute Working Paper No. 3.

Erceg, C. J., L. Guerrieri, and C. Gust (2005). Can Long-Run Restrictions Identify Technology Shocks? Journal of the European Economic Association 3, 1237-78.

Erceg, C. J., L. Guerrieri, and C. Gust (2006). SIGMA: A New Open Economy Model for Policy Analysis. Journal of International Central Banking 2(1), 1-50.

Erceg, C. J., L. Guerrieri, and C. Gust (2008). Trade Adjustment and the Composition of Trade. Journal of Economic Dynamics and Control forthcoming.

Erceg, C. J. and A. Levin (1996). Structures and the Dynamic Behavior of the Real Exchange Rate. Board of Governors of the Federal Reserve System, mimeo.

Faruqee, H., D. Laxton, D. Muir, and P. Pesenti (2005). Smooth Landing or Crash? ModelBased Scenarios of Global Current Account Rebalancing. National Bureau of Economic Research Working Paper 11583. 
Goldberg, L. S. and C. Tille (2006). Vehicle Currency Use in International Trade. mimeo, Federal Reserve Bank of New York.

Gopinath, G. and R. Rigobon (2006). Sticky Borders. National Bureau of Economic Research Working paper 12095.

Guerrieri, L., C. Gust, and D. López-Salido (2008). International Competition and Inflation: A New Keynesian Perspective. Board of Governors of the Federal Reserve System International Finance Discussion Papers 918.

Gust, C., S. Leduc, and R. Vigfusson (2006). Trade Integration, Competition, and the Decline in Exchange Rate Pass-through. Board of Governors of the Federal Reserve System International Finance Discussion Papers 864.

IMF (2005). United States: Selected Issues. Washington, D.C.: International Monetary Fund.

Kimball, M. (1995). The Quantitative Analytics of the Neomonetarist Model. Journal of Money, Credit, and Banking 27, 1241-77.

Lubik, T. A. and F. Schorfheide (2007). Do Central Banks Respond to Exchange Rate Movements? A Structural Investigation. Journal of Monetary Economics 54, 1069-1087.

Marazzi, M. and N. Sheets (2007). Declining Exchange Rate Pass-Through to U.S. Import Prices: The Potential Role of Global Factors. Journal of International Money and Finance 26, 924-947.

McCallum, B. T. and E. Nelson (2000). Monetary Policy for an Open Economy: An Alternative Framework with Optimizing Agents and Sticky Prices. Oxford Review of Economic Policy 16, 74-91.

Mendoza, E. (1991). Real Business Cycles in a Small Open Economy. American Economic Review 81, 797-818.

Mendoza, E. G., V. Quadrini, and J.-V. Rios-Rull (2007). Financial Integration, Financial Deepness, and Global Imbalances. National Bureau of Economic Research Working Paper 12909.

Nakamura, E. and J. Steinsson (2007). Five Facts About Prices: A Reevaluation of Menu Cost Models. Mimeo, Harvard University.

Obstfeld, M. and K. Rogoff (2000a). New Directions for Stochastic Open Economy Models. Journal of International Economics 50, 117-154.

Obstfeld, M. and K. Rogoff (2000b). Perspectives on OECD Capital Market Integration: Implications for U.S. Current Account Adjustment. In Global Economic Integration: Opportunities and Challenges, pp. 169-208. Federal Reserve Bank of Kansas City.

Obstfeld, M. and K. Rogoff (2004). The Unsustainable US Current Account Position Revisited. National Bureau of Economic Research Working Paper No. 10869.

Ramanarayanan, A. (2007). International Trade Dynamics with Intermediate Inputs. Federal Reserve Bank of Dallas, mimeo. 
Ruhl, K. (2005). The Elasticity Puzzle in International Economics. University of Texas at Austin, mimeo.

Schmitt-Grohe, S. and M. Uribe (2003). Closing Small Open Economy Models. Journal of International Economics 61, 163-185.

Taylor, J. (1993). Discretion versus policy rules in practice. Carnegie-Rochester Conference Series on Public Policy 39, 195-214.

Taylor, J. B. (1999). Staggered Price and Wage Setting in Macroeconomics. In J. Taylor and M. Woodford (Eds.), Handbook of Macroeconomics, Volume 1 of Handbooks in Economics Series. Elsevier Science B.V.

Turnovsky, S. (1985). Domestic and Foreign Disturbances in an Optimizing Model of Exchange-Rate Determination. Journal of International Money and Finance 4, 151-171.

Woodford, M. (2003). Interest 83 Prices: Foundations of a Theory of Monetary Policy. Princeton: Princeton University Press. 
Table 1: Trade Statistics ${ }^{a, b}$

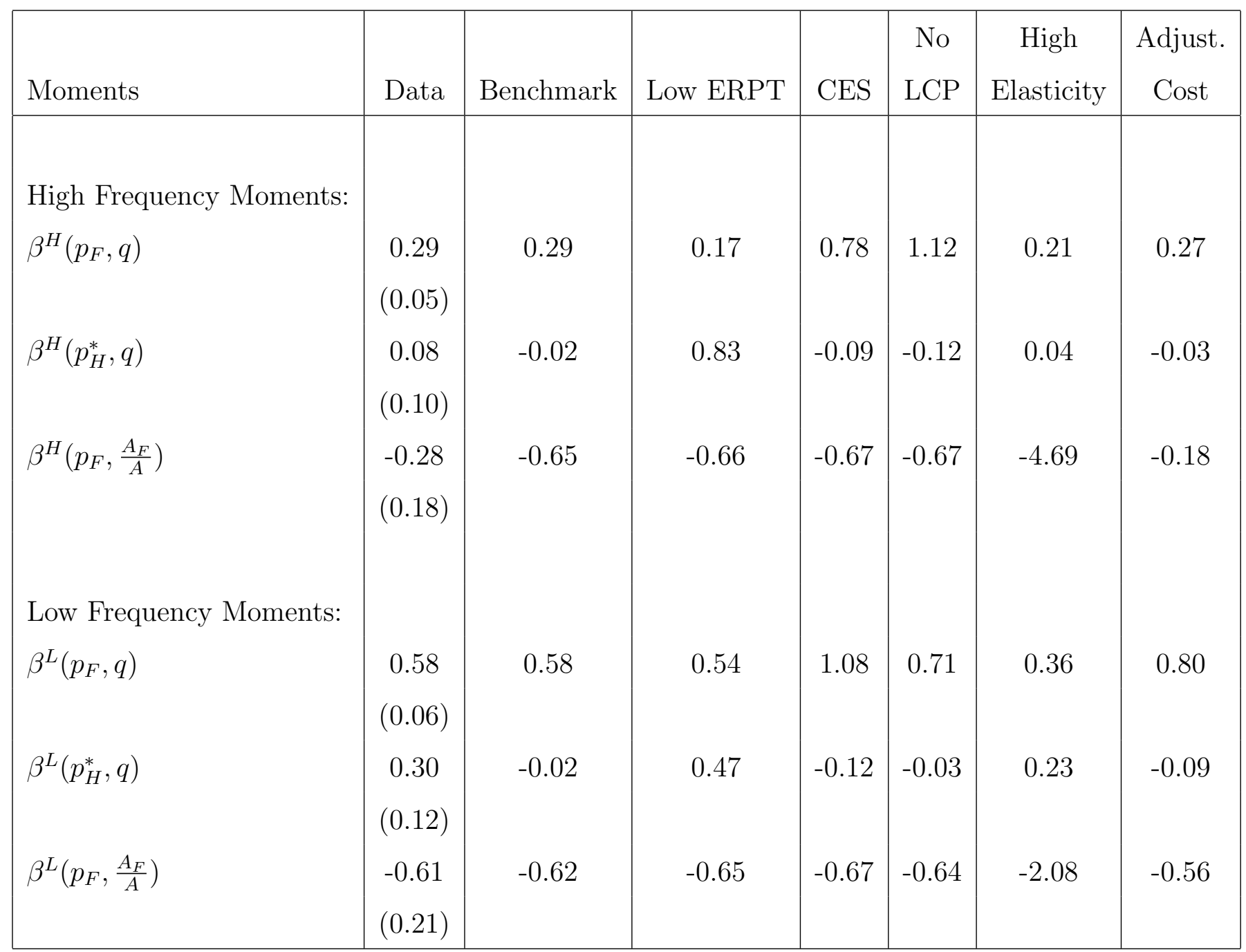

${ }^{a}$ Entries denote statistics based on U.S. data and different versions of our model at different frequencies. The superscript "H" denotes the statistic at periodicities of 2 to 8 quarters, and the superscript "L" denotes the statistic at periodicities of 20 to 40 quarters. Standard errors for the data are reported in parenthesis.

${ }^{b}$ The statistic $\beta(y, x)$ denotes the correlation between $x$ and $y, \rho(y, x)$, multiplied by the standard deviation of $y$ relative to the standard deviation of $x, \frac{\sigma_{y}}{\sigma_{x}}$ (i.e., $\beta(y, x)=\rho(y, x) \frac{\sigma_{y}}{\sigma_{x}}$.) 
Table 2: Business Cycle Statistics ${ }^{a, b}$

\begin{tabular}{|c|c|c|c|c|c|c|c|}
\hline Moments & Data & Benchmark & Low ERPT & CES & $\begin{array}{c}\text { No } \\
\text { LCP }\end{array}$ & $\begin{array}{c}\text { High } \\
\text { Elasticity }\end{array}$ & $\begin{array}{l}\text { Adjust } \\
\text { Cost }\end{array}$ \\
\hline$\sigma_{Y}$ & $\begin{array}{c}1.31 \\
(0.21)\end{array}$ & 1.31 & 1.31 & 1.35 & 1.59 & 1.42 & 1.31 \\
\hline$\sigma_{T B / Y}$ & $\begin{array}{c}0.37 \\
(0.03)\end{array}$ & 0.17 & 0.07 & 0.11 & 0.23 & 0.24 & 0.17 \\
\hline$\sigma_{C} / \sigma_{Y}$ & $\begin{array}{c}0.54 \\
(0.12)\end{array}$ & 0.66 & 0.70 & 0.59 & 0.52 & 0.63 & 0.58 \\
\hline$\sigma_{I} / \sigma_{Y}$ & $\begin{array}{c}3.62 \\
(0.68)\end{array}$ & 2.24 & 2.27 & 2.09 & 3.22 & 2.19 & 2.58 \\
\hline$\sigma_{q} / \sigma_{Y}$ & $\begin{array}{c}2.69 \\
(0.61)\end{array}$ & 1.59 & 1.65 & 1.60 & 1.23 & 0.37 & 1.97 \\
\hline$\sigma_{T O T} / \sigma_{q}$ & $\begin{array}{c}0.74 \\
(0.14)\end{array}$ & 0.52 & 0.61 & 1.13 & 0.89 & 0.16 & 0.77 \\
\hline Correlations: & & & & & & & \\
\hline$\rho(T O T, q)$ & $\begin{array}{c}0.34 \\
(0.19)\end{array}$ & 0.91 & -0.42 & 0.98 & 0.93 & 0.91 & 0.78 \\
\hline$\rho\left(Y, Y_{-1}\right)$ & $\begin{array}{c}0.94 \\
(0.31)\end{array}$ & 0.90 & 0.91 & 0.90 & 0.87 & 0.90 & 0.90 \\
\hline$\beta(\pi, q)$ & $\begin{array}{c}0.02 \\
(0.01)\end{array}$ & 0.02 & 0.02 & 0.02 & 0.01 & 0.04 & 0.01 \\
\hline
\end{tabular}

${ }^{a}$ Entries denote statistics based on U.S. data and different versions of our model at business cycle frequencies (i.e., periodicities between 6 and 32 quarters).

${ }^{b}$ The statistic $\beta(y, x)$ denotes the correlation between $x$ and $y, \rho(y, x)$, multiplied by the standard deviation of $y$ relative to the standard deviation of $x, \frac{\sigma_{y}}{\sigma_{x}}$ (i.e., $\beta(y, x)=\rho(y, x) \frac{\sigma_{y}}{\sigma_{x}}$.) 
Table 3: Estimated Parameter Values*

\begin{tabular}{|l|l|}
\hline$\Psi=0.846$ & $\theta_{F}=0.503$ \\
$\epsilon_{T}=0.785$ & $\rho_{Z}=0.99$ \\
$\sigma_{Z}=0.012$ & \\
\hline
\end{tabular}

*Estimates imply a value of $\rho=0.77, \nu=4.60$, and $\gamma=1.05$ given a calibrated value of $\mu=1.2$.

Table 4: Calibrated Parameter Values

\begin{tabular}{|l|l|}
\hline$\beta=(1.03)^{-0.25}$ & $\delta=0.025$ \\
$\chi=1$ & $\mu=1.2$ \\
$\phi_{b}=0.0001$ & $\alpha=0.4$ \\
$\frac{1+\rho_{a}}{\rho_{a}}=0.74$ & $\phi=0.2$ \\
$\eta=1$ & $\omega=0.25$ \\
$\theta_{N}=0.75$ & $\theta_{H}=0.75$ \\
$\gamma_{\pi}=1.5$ & $\gamma_{Y}=0.125$ \\
$\rho_{g}=0.98$ & $\sigma_{g}=0.016$ \\
$g=0.18$ & $\mu=1.2$ \\
\hline
\end{tabular}


Table 5: Response of Trade Prices and Quantities for Alternative Shocks ${ }^{a, b}$

\begin{tabular}{|c|c|c|c|c|c|}
\hline & $\begin{array}{c}\text { Real } \\
\text { Exchange Rate }\end{array}$ & Absorption & $\begin{array}{l}\text { Real } \\
\text { Trade }\end{array}$ & $\begin{array}{c}\text { Terms } \\
\text { of Trade }\end{array}$ & $\begin{array}{c}\text { Nominal Trade } \\
\text { (\% of GDP) }\end{array}$ \\
\hline \multicolumn{6}{|c|}{ Government Spending } \\
\hline \multicolumn{6}{|l|}{ Decrease } \\
\hline High ERPT & 0.41 & -2.93 & 3.95 & 0.50 & 0.36 \\
\hline Benchmark & 0.66 & -2.98 & 4.13 & 0.43 & 0.38 \\
\hline Low ERPT & 1.00 & -3.03 & 4.44 & 0.35 & 0.42 \\
\hline \multicolumn{6}{|c|}{ Monetary Expansion } \\
\hline High ERPT & 0.58 & 1.41 & -0.49 & 0.65 & -0.12 \\
\hline Benchmark & 0.64 & 1.54 & -0.88 & 0.25 & -0.12 \\
\hline Low ERPT & 1.00 & 1.68 & -2.44 & -1.57 & -0.09 \\
\hline \multicolumn{6}{|c|}{ Aggregate Technology } \\
\hline \multicolumn{6}{|l|}{ Increase } \\
\hline High ERPT & 0.95 & 0.68 & 0.78 & 1.05 & -0.03 \\
\hline Benchmark & 0.97 & 0.71 & 0.43 & 0.60 & -0.02 \\
\hline Low ERPT & 1.00 & 0.75 & 0.00 & 0.05 & -0.01 \\
\hline
\end{tabular}

${ }^{a}$ Entries refer to the response of each variable after 4 quarters. All variables except the nominal trade balance are expressed as a percent deviation from steady state. Real trade defined as the ratio of real exports to real imports. The nominal trade balance is expressed as a ratio to nominal output, and the units denote percentage point deviation from steady state.

${ }^{b}$ The shock is calibrated to induce a 1 percent depreciation in the real exchange rate after 4 quarters in the benchmark case of the Low ERPT scenario.

${ }^{c}$ High ERPT refers to the scenario in which home and foreign producers practice producer currency pricing, and Low ERPT refers to the scenario in which home and foreign producers price to market. 
Table 6: Response of Trade Balance to a Government Spending Shock under Alternative ERPT Assumptions ${ }^{a, b}$

\begin{tabular}{|c|c|c|c|c|c|}
\hline & $\begin{array}{c}\text { Real } \\
\text { Exchange Rate }\end{array}$ & Absorption & $\begin{array}{l}\text { Real } \\
\text { Trade }\end{array}$ & $\begin{array}{c}\text { Terms } \\
\text { of Trade }\end{array}$ & $\begin{array}{c}\text { Nominal Trade } \\
(\% \text { of GDP) }\end{array}$ \\
\hline \multicolumn{6}{|l|}{ Benchmark } \\
\hline High ERPT & 0.41 & -2.93 & 3.95 & 0.50 & 0.36 \\
\hline Low ERPT & 1.00 & -3.03 & 4.44 & 0.35 & 0.42 \\
\hline \multicolumn{6}{|l|}{ LCP/CES Demand } \\
\hline High ERPT & 0.41 & -2.79 & 3.80 & 0.51 & 0.34 \\
\hline Low ERPT & 0.43 & -2.81 & 3.89 & 0.58 & 0.34 \\
\hline \multicolumn{6}{|l|}{ No LCP/VES Demand } \\
\hline High ERPT & 0.41 & -2.93 & 3.95 & 0.50 & 0.36 \\
\hline Low ERPT & 0.92 & -2.83 & 4.15 & 0.58 & 0.37 \\
\hline \multicolumn{6}{|l|}{ 4-Qtr. LCP/VES Demand } \\
\hline High ERPT & 0.41 & -2.93 & 3.95 & 0.50 & 0.36 \\
\hline Low ERPT & 1.19 & -2.88 & 3.71 & -0.48 & 0.43 \\
\hline \multicolumn{6}{|l|}{ Smaller Distribution } \\
\hline High ERPT & 0.67 & -2.98 & 4.46 & 0.79 & 0.38 \\
\hline Low ERPT & 1.15 & -3.04 & 4.65 & 0.37 & 0.44 \\
\hline
\end{tabular}

${ }^{a}$ Entries refer to the response of each variable after 4 quarters. All variables except the nominal trade balance are expressed as a percent deviation from steady state. Real trade defined as the ratio of real exports to real imports. The nominal trade balance is expressed as a ratio to nominal output, and the units denote percentage point deviation from steady state. ${ }^{b}$ The shock is calibrated to induce a 1 percent depreciation in the real exchange rate after 4 quarters in the benchmark case of the Low ERPT scenario.

${ }^{c}$ High ERPT refers to the scenario in which home and foreign producers practice producer currency pricing, and Low ERPT refers to the scenario in which home and foreign producers price to market. 
Table 7: Response of Trade Balance to a Government Spending Shock under Alternative Monetary Policies ${ }^{a, b}$

\begin{tabular}{|l|c|c|c|c|c|}
\hline & $\begin{array}{c}\text { Real } \\
\text { Exchange Rate }\end{array}$ & Absorption & $\begin{array}{c}\text { Real } \\
\text { Trade }\end{array}$ & $\begin{array}{c}\text { Terms } \\
\text { of Trade }\end{array}$ & $\begin{array}{c}\text { Nominal Trade } \\
\text { (\% of GDP) }\end{array}$ \\
\hline $\begin{array}{l}\text { Benchmark/Taylor Rule } \\
\text { High ERPT }\end{array}$ & 0.15 & -4.15 & 4.93 & 0.23 & 0.49 \\
Low ERPT & 1.00 & -4.25 & 6.07 & 0.79 & 0.55 \\
Rule with exchange rate & 0.09 & -4.00 & 4.54 & 0.15 & 0.45 \\
$\quad$ High ERPT & 0.71 & -4.03 & 5.09 & 0.27 & 0.50 \\
Low ERPT & & & & & \\
Flexible Price Model & 0.57 & -3.93 & 5.08 & 0.52 & 0.47 \\
High ERPT & 1.39 & -3.96 & 5.74 & 0.65 & 0.53 \\
Low ERPT & & & & & \\
& & & & \\
\hline
\end{tabular}

${ }^{a}$ Entries refer to the response of each variable after 4 quarters. All variables except the nominal trade balance are expressed as a percent deviation from steady state. Real trade defined as the ratio of real exports to real imports. The nominal trade balance is expressed as a ratio to nominal output, and the units denote percentage point deviation from steady state.

${ }^{b}$ The shock is calibrated to induce a 1 percent depreciation in the real exchange rate after 4 quarters in the benchmark case of the Low ERPT scenario.

${ }^{c}$ High ERPT refers to the scenario in which home and foreign producers practice producer currency pricing, and Low ERPT refers to the scenario in which home and foreign producers price to market. 
Figure 1: Response to a Decrease in Government Spending

(Deviation from Steady State)
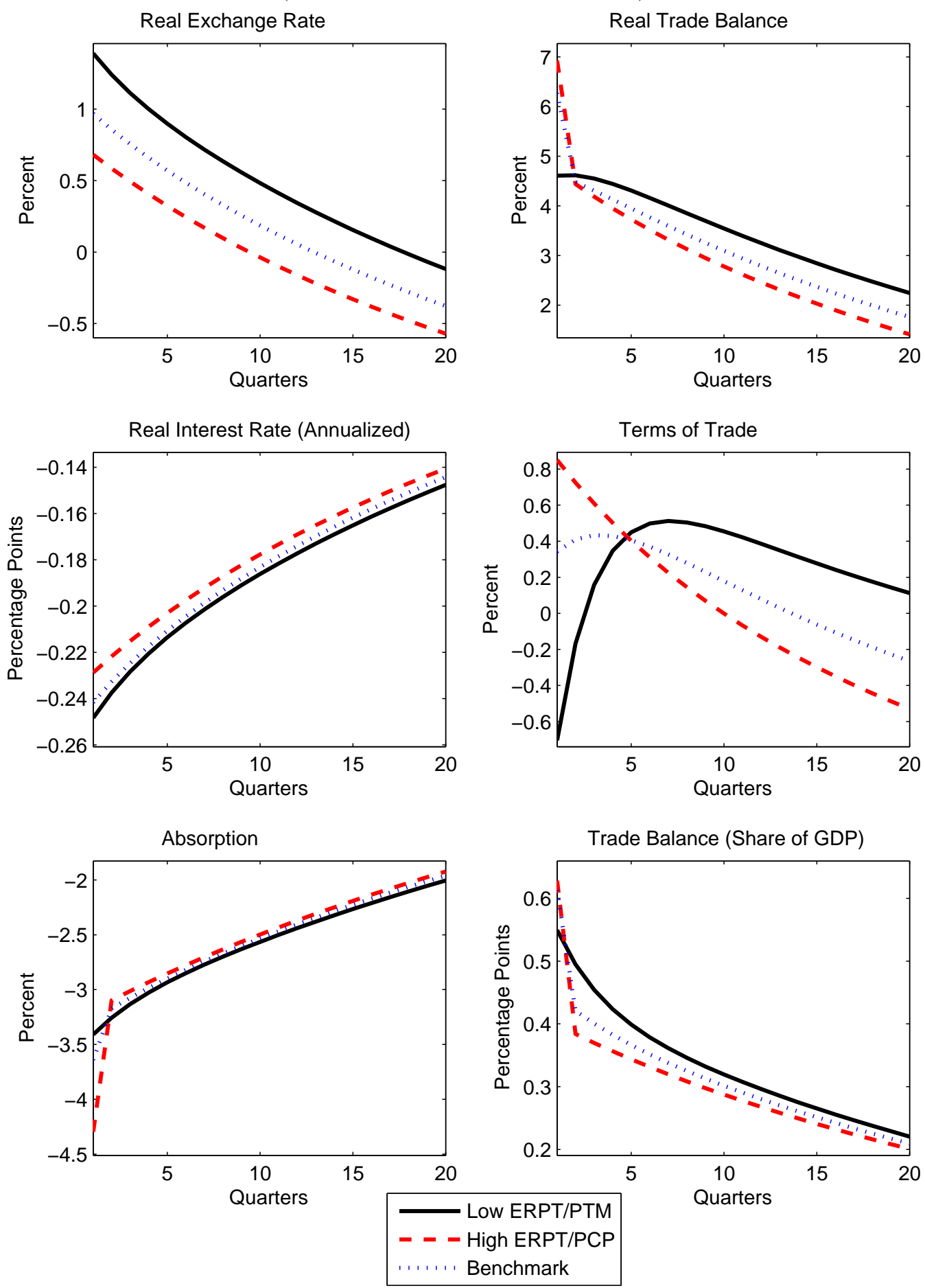
Figure 2: Response to a Decrease in Government Spending High Elasticity of Substitution Between Home and Foreign Goods

(Deviation from Steady State)
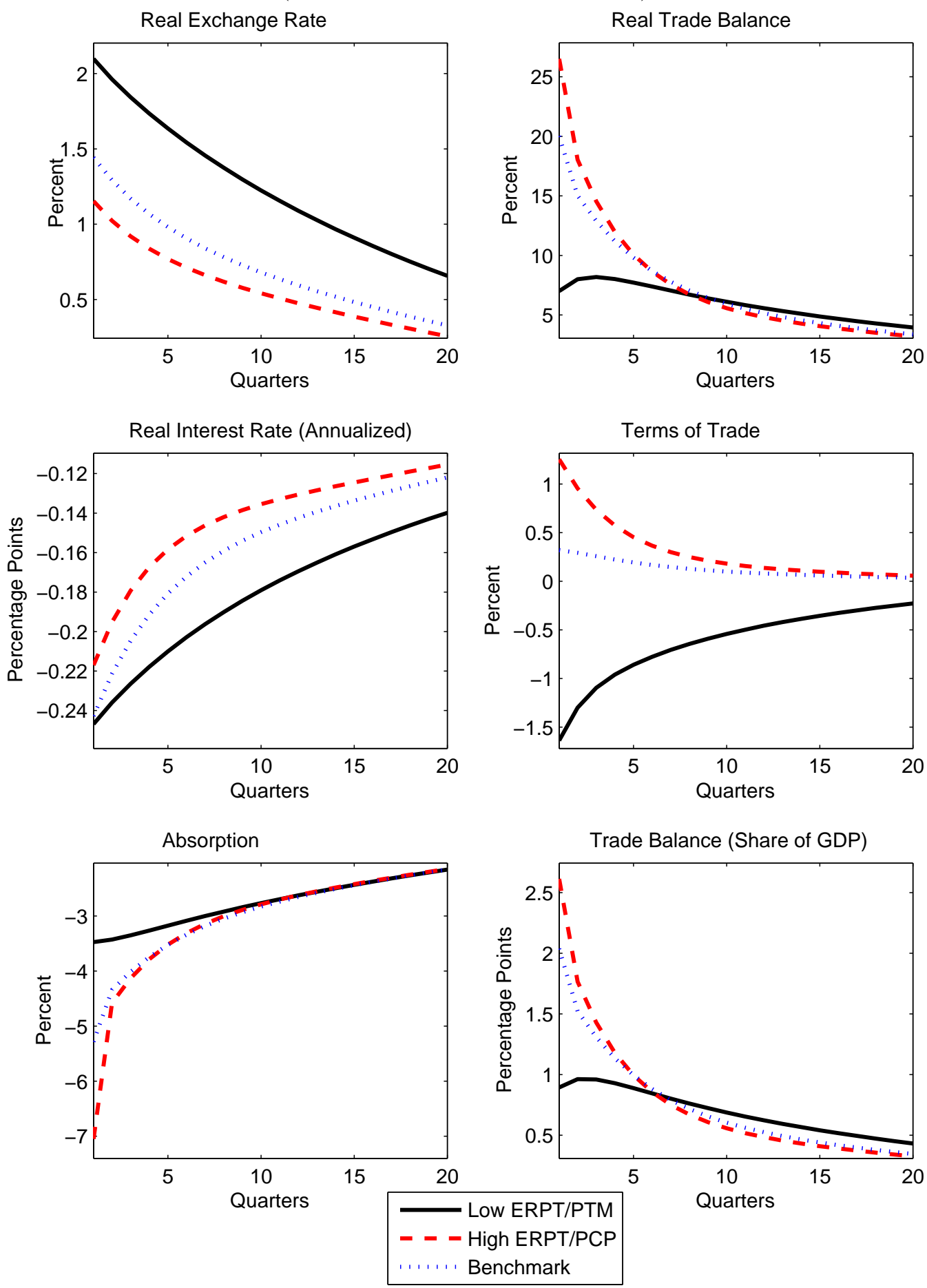
Figure 3: Response to a Decrease in Government Spending Model with Trade Adjustment Costs

(Deviation from Steady State)
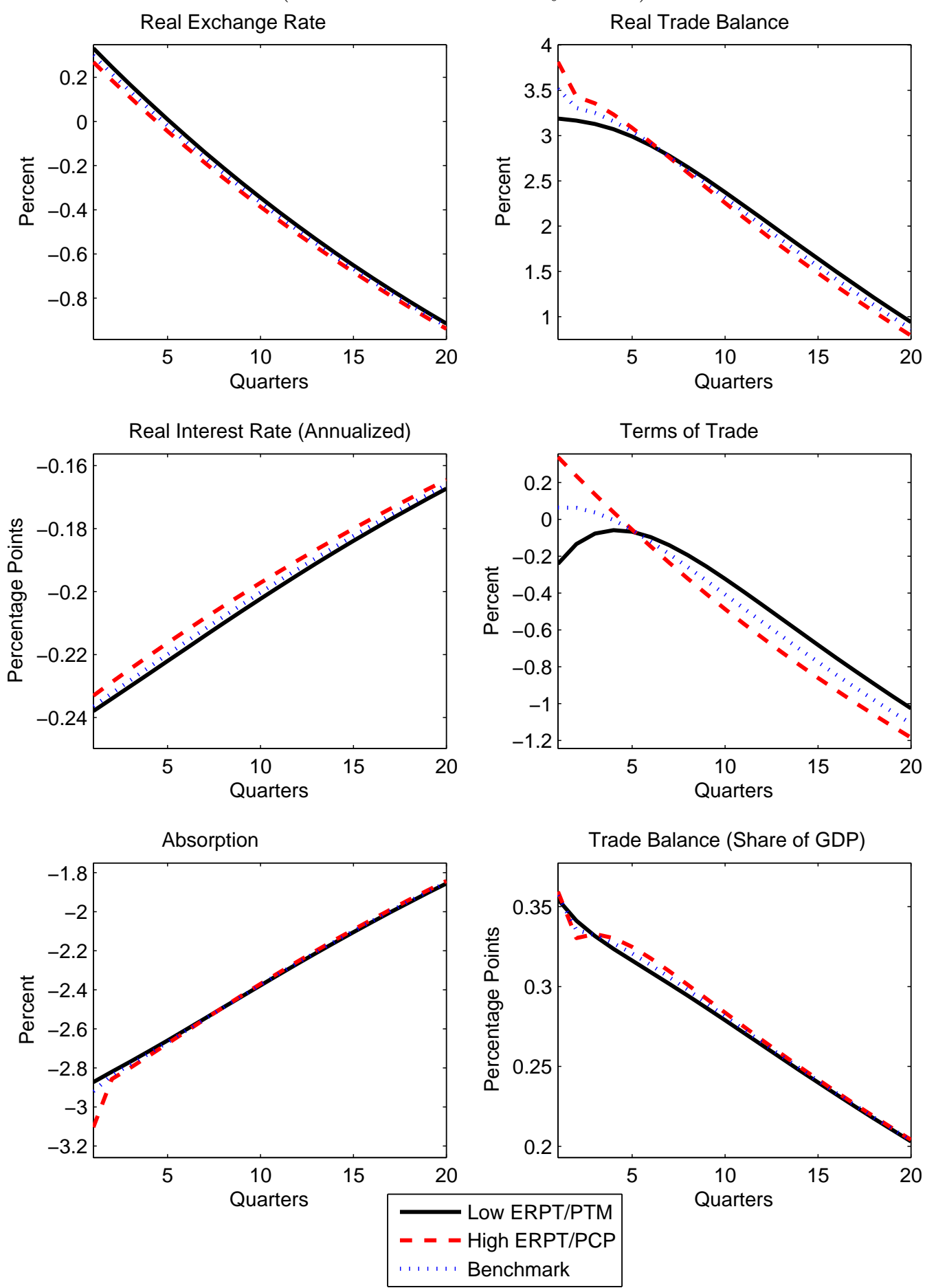